Portland State University

PDXScholar

10-11-1978

\title{
A Comparative Study of Language Deficits of Reservation and Urban Indian Children
}

Lezlie Kaye Pearce

Portland State University

Follow this and additional works at: https://pdxscholar.library.pdx.edu/open_access_etds

Part of the Indigenous Studies Commons, and the Speech Pathology and Audiology Commons Let us know how access to this document benefits you.

Recommended Citation

Pearce, Lezlie Kaye, "A Comparative Study of Language Deficits of Reservation and Urban Indian Children" (1978). Dissertations and Theses. Paper 2831.

https://doi.org/10.15760/etd.2825

This Thesis is brought to you for free and open access. It has been accepted for inclusion in Dissertations and Theses by an authorized administrator of PDXScholar. Please contact us if we can make this document more accessible: pdxscholar@pdx.edu. 
AN ABSTRACT OF THE THESIS OF Lezlie Kaye Pearce for the Master of Science in Speech Communication with an emphasis in Speech Pathology/ Audiology, presented October 11, 1978.

Title: A Comparative Study of Language Deficits of Reservation and Urban Indian Children.

APPROVED BY MEMBERS OF THE THESIS COMMITTEE:

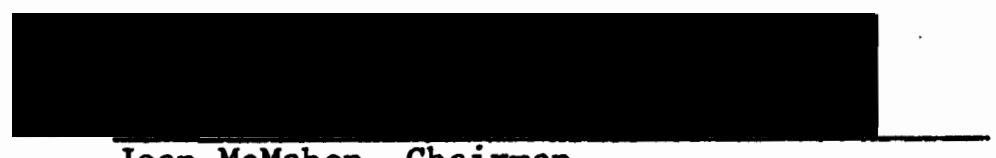

Joan McMahon, Chairman
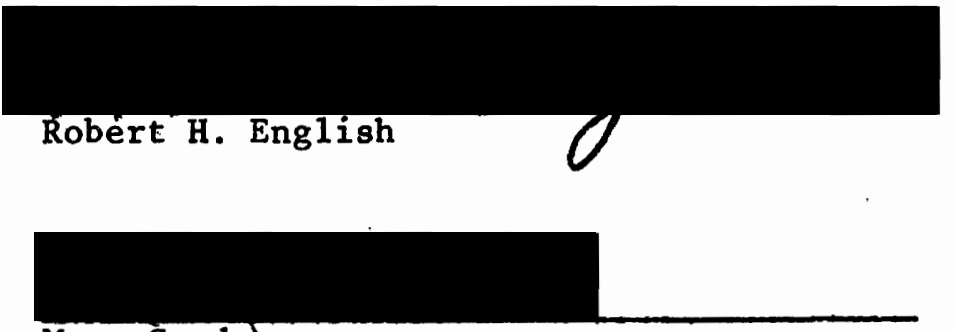

Mary Gordop

This study sought to determine if there are any differences in an analysis of language samples between urban Indian, reservation Indian, and urban White first-grade children. The Mean Length of Response (MLR) (Templin, 1957), Developmental Sentence Score (DSS) (Lee, 1974), and individual DSS items were used to analyze language used by the three groups of children. The study involved thirty-nine children, thirteen children in each group, between the ages of six years, six months, and seven years, four months. All subjects were screened to 
determine grade, residency, Indian blood, speech, language, hearing, and physical status. Testing for hearing vocabulary was performed at the beginning of the testing situation to determine eligibility for the study.

The study was designed to determine whether there was a significant difference in syntactical language development between the groups as measured by MLR, DSS, and the eight grammatical forms and sentence point from the DSS.

Results of the study indicate urban White children obtained significantly higher scores on MLR and DSS than either reservation or urban Indian children. Urban Indian children obtained significantly higher scores on DSS than reservation Indian children. No statistical significant difference was noted between urban and reservation Indian children on MLR; however, a trend toward significance was evidenced with urban Indian children displaying higher scores than reservation Indian children.

Results of individual DSS items indicated urban White children obtained significantly higher scores on indefinite pronoun, main verb, conjunction, and sentence point compared to urban Indian children. Urban White children also obtained significantly higher scores on personal pronoun, main verb, negative, conjunction, and sentence point compared to reservation Indian children. Urban Indian children obtained significantly higher scores on main verb and sentence point when compared to reservation Indian children.

The results of this study appear to indicate a positive 
correlation between a child's syntactical language development and his environment, which may be influenced by culture. 
A COMPARATIVE STUDY OF LANGUAGE DEFICITS OF RESERVATION AND URBAN INDIAN CHILDREN

\author{
by
}

LEZLIE KAYE PEARCE

A thesis submitted in partial fulfillment of the requirements for the degree of

MASTER OF SCIENCE IN SPEECH COMMUNICATION:

with an emphasis in SPEECH PATHOLOGY/AUDIOLOGY

Portland State University 1978 
TO THE OFFICE OF GRADUATE STUDIES AND RESEARCH:

The members of the Committee approve the thesis of Lezlie Kaye Pearce presented October 11, 1978.

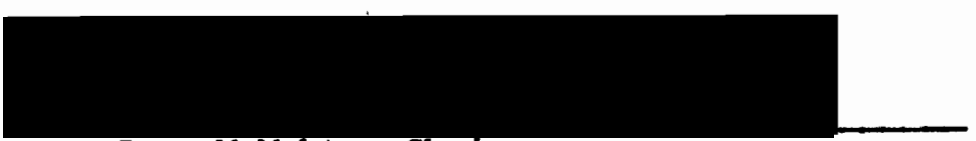

Joan McMahon, Chairman
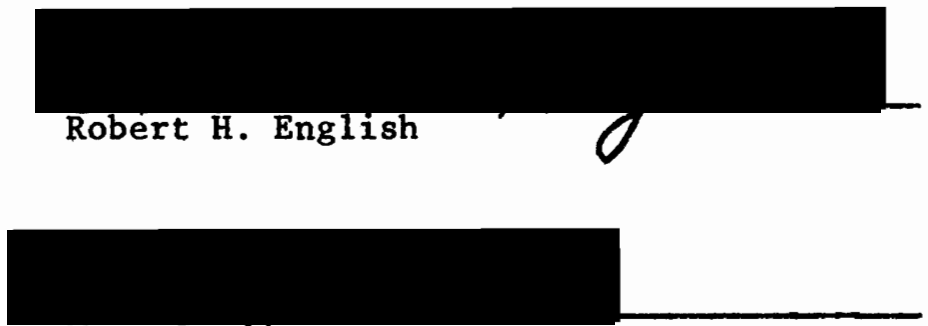

Mary Gordgn

APPROVED :

Roblert W. Vogelsanf

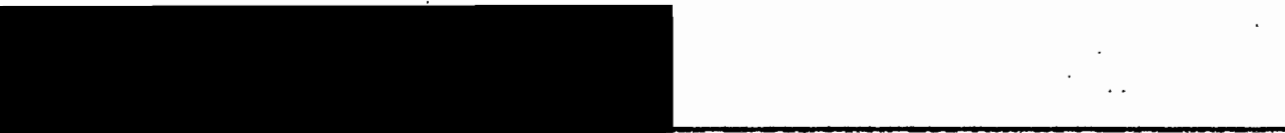

Stairley E. Rauch, Dean of Graduate Studies and Research 


\section{ACKNOWLEDGMENTS}

My sincere appreciation goes to Joan McMahon, my committee chairman and graduate advisor, for support and time generously given. Special thanks go to my committee members Dr. Robert English and Mary Gordon for their help.

To my friends my deep appreciation for the many words of support and encouragement during my graduate study. A special thank you goes to Warren for the encouragement and never-ending support when it was needed most.

I dedicate this thesis to my parents, Robert and Loretta Pearce, and my grandparents, Gene and Jean Dunning, who always believed I could do it. My love and appreciation go to them for their support and patience during my graduate study. Without their help this would not have been possible. 
TABLE OF CONTENTS

PAGE

ACKNOWLEDGMENTS . . .. . . . . . . . . . . . . . . iii

LIST OF TABLES . . . . . . . . . . . . . . . . . . . . . . vi v vi

LIST OF FIGURES . . . . . . . . . . . . . . . . . . . v vii

CHAPTER

I INTRODUCTION AND STATEMENT OF PURPOSE . . . . . . . . . 1

II REVIEW OF THE LITERATURE . . . . . . . . . . . . 5

Definition of an Indian . . . . . . . . . . 5

Intelligence . . . . . . . . . . . . . 7

Culture .................... . . 8

Language . . . . . . . . . . . . . 10

Education . . . . . . . . . . . . . 13

IIT METHODS AND PROCEDURES . . . . . . . . . . . . 18

Subjects . . . . . . . . . . . . . . 18

Intelligence

Residence

Indian Blood

Speech, Hearing, and Physical Status

Instrumentation . . . . . . . . . . . . 19

Procedures . . . . . . . . . . . . . . 20

Test Administration

Scoring

Data Analysis . . . . . . . . . . . . . 
CHAPTER

PAGE

IV RESULTS AND DISCUSSION : . . . . . . . . . . .

Results . . . . . . . . . . . . . .

Analysis of Individual DSS Items

Discussion . . . . . . . . . . . . .

$\mathrm{V}$ SUMMARY AND IMPLICATIONS . . . . . . . . . . . . .

Summary . • . • . . . . . . . • . • •

Implications for Clinic and Future Research . . .

Clinic

Research

SELECTED BIBLIOGRAPHY . . . . . . . . . . . . . . . .

APPENDICES

A PERMISSION REQUEST . • . . . . . . . . . . . 55

B DEVELOPMENTAL SENTENCE SCORING . . . . . . . . . 56

C MLR RULES . . . . . . . . . . . . . . . . 58

D PEABODY PICTURE VOCABULARY TEST, FORM A . . . . . . 60

E DSS RULES . . . . . . . ............ . . 62

F TYPICAL LANGUAGE SAMPLE URBAN INDIAN GROUP A . . . . 63

G TYPICAL LANGUAGE SAMPLE RESERVATION INDIAN GROUP B • 65

H TYPICAL LANGUAGE SAMPLE URBAN WHITE GROUP C . . . . . 67

I AGE, HEARING VOCABULARY, AND SCORES BY SUBJECT

IN URBAN GROUP A . . . . . . . . . . . .

J AGE, HEARING VOCABULARY, AND SCORES BY SUBJECT IN RESERVATION INDIAN GROUP B . . . . . . . . .

$\mathrm{K}$ AGE, HEARING VOCABULARY, AND SCORES BY SUBJECT IN URBAN WHITE GROUP C . . . . . . . . . . • • 


\section{LIST OF TABLES}

TABLE

PAGE

I Comparison of MLR Scores . . . . . . . . . . . 24

II Comparison of DSS Scores . . . . . . . . . . 24

III Comparison of Indefinite Pronoun Scores . . . . . . 27

IV Comparison of Personal Pronoun Scores . . . . . . . . 27

$\mathrm{V}$ Comparison of Main Verb Scores . . . . . . . . . 28

VI Comparison of Secondary Verb Scores . . . . . . . . . 29

III Comparison of Negative Scores . . . . . . . . . . 29

[II Comparison of Conjunction Scores . . . . . . . . 30

IX Comparison of Interrogative Reversal Scores . . . . 31

$\mathrm{X}$ Comparison of Wh-Question Scores . . . . . . . 32

XI Comparison of Sentence Point Scores . . . . . . . . 33 


\section{LIST OF FIGURES}

1 A Comparison of the Mean and Range for MLR Scores of Each Group . . . . . . . . . . . . . . . .

2 A Comparison of the Mean and Range for DSS Scores of Each Group . . . . . . . . . . . . . . . .

3 A Comparison of the Mean and Range for Indefinite Pronoun Scores of Each Group . . . . . . . . .

4 A Comparison of the Mean and Range for Main Verb of Each Group . . . . . . . . . . . . . . .

5 A Comparison of the Mean and Range for Conjunction of Each Group . . . . . . . . . . . . . . . .

6 A Comparison of the Mean and Range for Sentence Point of Each Group . . . . . . . . . . . . .

7 A Comparison of the Mean and Range for Personal Pronoun of Each Group . . . . . . . . . . . .

8 A Comparison of the Mean and Range for Negative of Each Group . . . . . . . . . . . . . . .

9 A Comparison of the Mean and Range for Secondary Verb of Each Group . . . . . . . . . . . . .

10 A Comparison of the Mean and Range for Interrogative Reversal of Each Group . . . . . . . . . . . . .

11 A Comparison of the Mean and Range for Wh-Question of Each Group . . . . . . . . . . . . . . .

12 A Display of Individual Scores for Each Group as Compared to MLR Norms

13 A Display of Individual Scores for Each Group as Compared to DSS Norms 
CHAPTER I

INTRODUCTION AND STATEMENT OF PURPOSE

\section{Introduction}

One of the growing areas of interest in the study of language and psycholinguistics is that of language differences among cultural groups. In this country the language structure of Blacks has been the most widely studied of the minority language patterns, but there is now a growing interest in the cultural language differences of the American Indian .

Today, American Indians constitute a rapidly growing population. Nearly 800,000 Indians were counted in the 1970 census, about 50 percent more than in 1960 (Osborn, 1970).

It is not enough to compare the achievement of Indian youth.with that of other minority groups, such as Blacks, Mexican Americans, and Puerto Ricans. According to Fuchs and Havighurst (1973), these groups are much more fully committed to participate in the dominant culture: Most Indians, however, are members of tribes which have now or had, until recently, a non-Western culture, modified over the years of contact with others, but not as fully committed to acculturation as most minority groups in this nation (Fuchs and Havighurst, 1973).

Indian children attend school in a wide variety of settings. Some live in remote isolated areas, others in major metropolitan centers of the nation. Indian communities vary according to employment; 
language spoken in the home, degree of Indian ancestry, types of schools attended, and proportion of non-Indians in the schools attended by the children.

Most Indian children are affected both by their Indian culture and by the culture of the White society that surrounds them. The Indian child today lives within two cultures. On the one hand, there is the traditional way of life represented by the culture of Indians. On the other hand, there is the modern American civilization with its own distinctive patterns and sets of values. Modern American Indians may adopt a new culture with few components of the other two cultures; they may favor one culture and reject the other, or may work out some combination of the two (Fuchs and Havighurst, 1973).

Indians are in a lower position than Blacks on socioeconomic indices such as per family income, infant mortality, unemployment, and education of parents, but compared to Blacks test scores of Indian children reveal a specific deficit in language with lesser deficits in other areas (Casden and John, 1968). The, Gese11 Developmental Scales reveal Indian children show consistently lower scores compared to the norms in their languạge achievement at all age levels tested (Fischler, 1966).

The urban Indian apparently has a stronger sense of separation from his culture than does the reservation Indian, which appears to be reflected in their academic achievement (National study, 1971). It has been suggested that as this cultural environment of Indian children approached that of White children in the public school, the Indian educational achievements more closely approached the scores of White 
pupils in public schools than did the scores of Indian pupils in reservation schools (Coleman, 1966).

Although urban Indians are increasingly the subject of attention in many studies, the urban experience of their children has received relatively little attention (National Study, 1971). The impression gained from the literature is Indian children are not acquiring the skills needed and desired in the use of the English language (Berry, 1968). There are similarities between the reservation and urban Indian child, but the communities where the Indian children live and the schools they attend yary considerably. It appears the degree of contact with the "White" culture affects the language development of the Indian child. The verbal skills of urban Indian children more closely approximate White norms than do those of reservation Indian children (Bowd, 1974).

There is a paucity of empirical evidence dealing with reservation and urban Indian children. The need for research in the area of language is revealed by the review of the existing 1 iterature. A concern for the lack of research involving both urban and reservation Indian children was expressed by Great Falls Public Schools Superintendent, Dr. Harold Wenass; Indian Affairs Director, Great Falls Public Schools, Dr. Murton McCluskey; Follow Through Program Director, Great Falls Public Schools, Faye Lesmeister; and Head Start Director, Great Falls, Montana, Karen Upham. This expressed need gave importance to the present project in order to aid the Indian child's educational advancement (Great Falls, 1977). 


\section{Statement of Purpose}

The purpose of this investigation was to compare the results of spontaneous language sample analyses of reservation Indian children, urban Indian children, and urban White children. More specifically, language samples from these three groups of children were analyzed using the Mean Length of Response (MLR) (Temp1in, 1957) and Developmental Sentence Score (DSS) (Lee, 1974) computations, and if differences were found, an analysis of individual DSS items was to be made in order to answer three essential questions:

1) Does a comparison of urban White children and urban Indian children yield a significant difference in syntactical language development? If so, in what ways?

2) Does a comparison of urban Indian children and reservation Indian children yield a significant difference in syntactical language development? If so, in what ways?

3) Does a comparison of urban White children and reservation Indian children yield a significant difference in syntactical language development? If 80 , in what ways? 
CHAPTER II

REVIEW OF THE LITERATURE

Many Indian children begin their formal education with little ski11 in using the English language. The language handicap grows increasingly greater as the Indian child moves through school (Blossom, 1962). This review of the literature begins with a discussion of the definition of an Indian as used in the present investigation. Intelligence, culture, and education are then discussed in relation to the Indian child and language.

\section{Definition of an Indian}

Who is an Indian?. In 1970, a person was considered to be an Indian if he declared himself to be one or was identified as one by his tribe. This relatively straightforward definition, according to self-identification or recognition, includes a wide range of persons (Fuchs and Havighurst, 1973).

Some persons are on the rolls of organized tribes, others are not; some Indians maintain traditional life styles and are frequently referred to as "full bloods" although they may be of mixed ancestry, others represent various degrees of acculturation in relation to the white society; some live in isolated rural regions, others in major industrial centers; some speak a native language as a home language, others have limited comprehension of an Indian language or none at all; some tribal members are "progressive" in that they lean toward institutions and political structures removed from traditional kinship and religious systems of political control, others are "conservative,". their allegiance remaining with the traditional systems of political control (Fuchs and Havighurst, 1973). 
The Indian, in order to receive tribal benefits, is an individual who is enrolled on the tribal census roll book. Enrollment for each tribal group varies from tribe to tribe, because each tribe has its own constitutional by-laws which set forth the specific qualifications for enrollment into the tribe. A large percentage of Indians continue to live on reservations:

A reservation is a tract of land owned by a tribe which is held in trust by the federal government. Land within a reservation can include that which is covered by exclusive titles, independent Indian communities, and Indian allotments. There exist approximately 300 separate Indian land units under the administration of the Bureau of Indian Affairs, along with scattered allotments in the public domain (Washburn, 1971).

The environment on the reservation seems to have constraints too strong for many of the residents, and migration away from the reservation began with the advent of World War II. The Bureau of Indian Affairs estimates in the decade preceding 1972, 200,000 Indian people moved to urban areas (Sorkin, 1971). In 1970, according to U.S. Census reports, there were forty cities of 50,000 or more which contained at least 1,000 Indian people.

This study is concerned with the portion of the Indian population, the Blackfoot, composed of a confederation of tribes consisting of Blackfoot, Bloods, and Piegans. The Bureau of Indian Affairs figures show there are approximately 9,000 enrolled members of this tribe and more than half live on the reservation (Duffy, 1972). The Blackfoot Indian Reservation is bounded on the west by Glacier National Park 
and reaches eastward for approximately forty-five miles. Reservation lands lie in both Glacier and Pondera Counties in Montana (Miller, 1962). Great Falls, Montana, has the largest Indian population of any city in the state with over 1,200 Indians, of which approximately 25 percent are Blackfoot (Duffy, 1972).

\section{Intelligence}

Indian children apparently are not different from the children of other social or racial groups in their ability to perceive, to think, and to learn (National Study, 1971). There is no reason to suppose Indian children are basically or genetically less or more intelligent than other children in America. The best evidence is they are the same at birth; and their experiences in the early years in their family and school tend to give them certain advantages and disadvantages compared with non-Indian children who grow up in other environments (Fuchs and Havighurst, 1973):

Intelligence studies of Indian children as measured by the California Achievement Test support the contention that the verbal component in tests of intelligence handicaps the Indian child (Roessel, 1962).

In a study using Indian children of five tribes (Navaho, Hopi, Zuni, Zia, and Papago), a non-verbal test of intelligence showed a considerable superiority of Indian children over White children (Havighurst, 1946). The test utilized was the Goodenough Draw-A-Man Test. The Indian's power of observation, memory, alertness, and attention to details seems to combine to contribute to these results 
(Havighurst and Hilkevitch, 1944).

It follows from these considerations that the lower average language and school achievement of Indian children must be due to factors other than natural or native ability. School achievement is well known to be related to a child's experience in his family, to his school experience, and to his inherited intellectual ability (Coombs, Kron, Collister, and Anderson, 1958). Since Indian children do not differ from other groups of children in their inherited intellectual ability, as far as is known, group differences in language and school achievement likely are due to family, school, and/or other social factors which affect the lives of Indian children (Fuchs and Havighurst, 1973).

\section{Cu1ture}

A child's success in school depends largely on the help and encouragement he has received from his parents. The Coleman study (1966) investigated the relationship between both family background and academic achievement and proved this relationship to be far more decisive than had been suggested in prior studies.

A theme appearing throughout the literature is that the Indian child comes from a home environment which is anything but conducive to academic success (Rist, 1961; and Branchard, 1953). The Mizen survey (1966) reads: "Housing is very inadequate, no sewage facilities are available, ninety percent of the housing units are overcrowded and water comes from unapproved sources." Mizen related the Indian child's poor academic success to these home conditions.

Branchard (1953) found the North Dakota Chippewas achieved 
significantly lower scores on the California Achievement Test than did their White schoolmates. A comparison based on several skills revealed the Indian pupil compared best in spelling and least well in reading vocabulary; which Branchard attributed to the importance placed on visual experiences within the culture. There was a wide difference between scores on reading and spelling, with the comparative achievement of the Indian pupils in spelling being significantly higher than for any of the other skills. Branchard (1953) attributed the inferiority of performatice to the Indian child's poor home environment in that, "Parents have had 1ittle schooling, many homes do not have radios, magazines, newspapers, etc."

Some social scientists believe the reservation is the only transmitter of Indian tradition (Lesser, 1961). When Indians leave behind traditional religious ceremonies, crafts, celebrations, and feasts that are unique to their tribes and reservations, they leave behind a group of people for whom these events and activities have a special meaning. This places the urban Indian in a difficult position relative to carrying on his culture and traditions (01iver and Peterson, 1975).

Several generalizations have been made about present-day Indian societies, but it must be kept in mind there are exceptions. The Indian way of life involves: attention to concrete realities of the present; having no word for time; generosity; individual autonomy; and dependence upon supernatural power (Roesse1, 1962). In contrast, major themes such as achievement and success, work and activity, efficiency and practicality, progress, material comfort, freedom and equality, and conformity are powerful forces in the dominant White culture, and 
taught as ideals in the public schools.

The Indian believes profoundly in silence, which is the sign of a perfect equilibrium. Silence is the balance of body, mind, and spirit (Osborn, 1973). Most Indian children are taught to be seen, but not heard, when peers and adults are present. This training is likely to affect the child's verbal behavior.

Whether or not the Indian child is "culturally deprived" is debatable, and the decision depends on one's understanding of deprivation; however, that he begins his formal education with a cultural heritage which differs appreciably from that of an urban school cannot be doubted. It is often stated the conflict of cultures which develops in the school situation is a major obstacle to the Indian child's academic success (Berry, 1968). The cultural factors which depress school achievement are complex, involving ability, the family, the school itself, and the community. They involve the complexities of cultural change in the Indian communities themselves, as well as the problems encountered by native Americans in relation to the larger society.

\section{Language}

Even for English-speaking Indians, language remains an aspect of behavior influenced by cultural conflict. This conflict may be reflected by both parents' behavior in the setting for language learning within the family, and in the child's restricted verbal performance in the testing situation itself (Fischler, 1966). In a study by Bowd (1974), results indicated the use of English in the home relates to vocabulary level among Indian children. A measure of verbal ability in 
English, the Mili Hill Vocabulary Scale, was administered to Indian children. It was suggested the observed depressed verbal ability scores of the children, or together with their resultant underachievement at school, may stem from the quality of English used in the home. Hawthorn (1967), in an extensive survey of several Indian communities in Canada, observed standard everyday conversations among Indian children and adults are severely limited. Questions are often answered in monosyllables, while custom frequently demands silence from children in the presence of adults. The English spoken by adults is often inaccurate and limited in vocabulary, and reading is virtually unknown. It appeared these factors may have adversely affected the verbal performance of the Indian children on the Mill Hill Vocabulary Scale.

Throughout the literature dealing with Indian Children, it is suggested their style of learning is more visual than verbal. In assessing the experiential background of Indian children, Mickelson and Galloway (1973) discovered Indian communication does not stress oral language. In addition, many of the children appeared to manifest characteristics referred to in the literature as being typical of the educationally disadvantaged child: lack of self-confidence; paucity of educational stimulus in the home; inadequate physical care and undernourishment; and impoverishment of language ski1ls. 01iver (1975) pointed out young Indians use gestures and seldom use words to communicate. John (1972) contrasts the learning style of the Navajo child with that of the urban, White middle-class child in this way: "The urban middle-class child is expected to display his growing skills through language while the Indian child is a doer." 
Visual learning may be reflected in several different performances. An academic skill such as spelling is partly a matter of visual discrimination. Indian children demonstrate relative superiority in this skill as measured by Coleman (1966). In the academic achievement of 13,000 Indian children in eleven states, Coombs et al. (1950) alsq found relative to their non-Indian schoolmates, Indian children do poorest in reading vocabulary and best in spelling.

Little has been published regarding specific language deficits of Indian children. Cultural differences in children's concepts of reading and writing were, studied by oliver (1975); results reported Indian children demonstrate, poorer knowledge of grammatical units of speech and writing than White children. Administration of the Boehm Test of Basic Concepts revealed scores significantly lower for Indian children in the development of verbal concepts when compared with their nonIndian peers. Mickelson and Galloway (1969) focused on the quality of verbalization assessed through the use of a test of language patterns. The Indian children demonstrated the most difficulty with indirect object, future tense, and possessive. Present indicative construction was demonstrated with the highest percent correct. Language patterns examined by the test, were the use of negatives, prepositions, possessive pronouns, verb "to be," active voice, passive voice, future tense, past tense, present indicative, adjectival construction, and indirect object. Oral language production of both urban and reservation Indians was studied by Fry and Johnson (1973) by means of a language sample. Reservation children tended to use a simple structure composed of only a subject and verb approximately twice as much as the urban Indian 
children. Urban Indians made greater use of secondary verbs than did the children on the reservation.

A fundamental difference lies in the method of learning by the Indian when compared to Whites. This difference creates an important discontinuity in the enculturation process of the children. Indian children typically learn by observation, manipulation, and experimentation in their native setting, but they must learn by verbal instruction, reading, and writing in the classroom (Rohner, 1965).

\section{Education}

There are many who place the blame for the Indian child's academic failures on the schools themselves, rather than the parents, children, teachers, community, and/or cultural barriers. The apparent lack of academic success within various cultural groups, especially lowerclass Blacks, Whites, Chicanos, and Indians, is a major educational issue (Anastasiow, 1972). Hardy (1970) has further noted a high incidence of language, speech, and reading problems is known to exist among culturally disadvantaged children. However, Hardy attributed these significant problems to the child's environment, rather than to the schools, since it frequently fails to provide stimulation and language growth and adequate (by middle-class standards) models or patterns to develop acceptable and competitive speech habits.

Frequently suggested as explanations of the low school achievement of the Indian child are: their concepts; attitude and disposition; conformance to, nature rather than domination of it; and social withdrawal in the school setting. These same four sources of conflict 
appear in Zintz's. (1963) contrasts between the values of the Navajo and Pueblo with White culture.

The young Indian children in school, then, are the product of whatever set of cultural forces have taught them to think, react, value, believe, or act in certain modes (Mickelson and Galloway, 1973). The chances of the Indian child becoming a fully functioning member in the mainstream of American society, according to Osborn (1970), appear to depend upon his ability to succeed in school. Further, he believed the "time schedule" or curriculum progression of the public schools has been established by the progress of middle-class children and, consequently, had presented a very serious problem for the Indian child. Phillips (1972) learned Indian children show a great deal of reluctance to talk in class and they participate less and less as they progress through school. She was aware of the cultural contexts that determine when speaking is socially appropriate. She reported Indian children are not culturally oriented to the ways in which classroom learning generally takes place. Provance (1963) reported Indian children were not motivated by rewards, were embarrassed to receive praise, were accustomed to great permissiveness, had great respect for individual rights, were resentful of pressure or insistence, and many never wanted to appear to know more than others in the group so would refuse to answer questions. Phillips (1972) reaffirmed the belief that when Indian children do speak, they speak very softly, often in tones inaudible to a person more than a few feet away, and in utterances typically briefer than those of their non-Indian counterparts. Though attentive to the teacher's yoice, these children tend to watch her 
actions (zintz, 1976).

In 1944 the Bureau of Indian Affairs undertook a study of Indian education. They questioned how the Indians' educational achievement compared with that of White children. A monograph by Peterson (1948) recorded the first full-scale evaluation of the schoolwork of Indian children. This study offered further evidence of the fact Indian pupils do not achieve as well in the basic skill subjects as white pupils. The results showed a wide variation among the Indians of various cultural backgrounds and home environments, but Indian students attending public schools with non-Indian children did better on reading, arithmetic, and, language than Indian children attending other types of schools, such as Federal and mission schools.

A follow-up study by Anderson (1953) and others gave more consideration to student achievement in relation to cultural and home backgrounds. Utilizing a testing program it was established that as the cultural and educational environment of the Indian children approached that of White children in the public school, the Indian educational achievements more closely matched those of White children.

In an extension of the Anderson study made by Coombs et a1. (1958), 23,000 pupils (42 percent White) were tested to determine what relationship exists between academic achievement of Indian children and certain environmental factors. On the basis of achievement, the results ranked as follows: White pupils in public schools; Indian pupils in public schools; Indian pupils in Federal schools; and Indian pupils in mission schools. They concluded the chief hinderance in educational achievement of Indian children was lack of "acculturation" 
with the best "indices of acculturation" being blood quantum and preschool language. With few exceptions, the higher ranking group had less Indian blood than the others and spoke more English before entering school.

Innumerable sma11-scale studies have been made, chiefly in the form of theses and dissertations, and they tend to support the principal findings of the Peterson, Anderson, and Coombs surveys. Penoi (1956) administered the California Achievement Test in three Federal boarding schools in Oklahoma, and found two-thirds of the pupils placed below their grade levels. Felber (1955) reported on the poor academic achievement of Indian pupils in the public schools of South Dakota, using school records, and personal interviews, and attributed the failure to their impoverished home environment. Deissler (1962), using the Iowa Test of Educational Development, studied Indian students in South Dakota public schools, and found they scored below state norms on a11 tests, This should not be interpreted to mean Federal or reservation schools are inferior; in many of these schools the enrollment consists largely of young Indians whose families have preserved their traditional isolation from White society (Fuchs and Havighurst, 1973). The public schools on the reservations must be willing to effect changes and transmit the essential aspects of the,dominant non-Indian culture and still be responsive to the needs of the individual student and the Indian culture present on the reservation, (Barlow, 1973).

A review of the literature in the education of the Indian reveals a tremendous need for testing of specific deficits in the language of urban and reservation Indian children. As educators address them- 
selves to the challenges and contrasts presented by American Indian students in the classrooms, it must be with enlightened awareness, and an expanded appreciation of the peculiarly crucial role played by spoken communication in the development and advancement of Indian cultures (Osborn, 1973), 


\section{METHODS AND PROCEDURES}

\section{Subjects}

Three groups of children ranging in age from six years, six months, to seven years, four months, were chosen to participate in this investigation. The three groups consisted of the urban Indian Group A, chosen by the Director of Indian Affairs in the Great Falls school district, Great Falls, Montana; reservation Indian Group B, chosen by the Director of Speech Pathology on the Blackfoot Indian Reservation, Browning, Montana; and the control White Group C, randomly selected from the Great Falls, Montana, public schools.

A parental permission form was sent home with each subject of the prospective groups (see Appendix A).

No attempt was made to control for age, sex, or socioeconomic status: Thirty-nine children were included in the investigation with thirteen in each group. The mean chronological age for Group A was 6.89, for Group B 6.91, and for control Group C 6.84 .

\section{Intelligence}

An estimation of the child's mental age through measurement of hearing vocabulary was provided by the Peabody Picture Vocabulary Test (PPVT), Form A. Children scoring between 85 to 115 were considered eligible for the study, since this has been suggested as the range of 
normal for the PPVT by Dunn (1959).

\section{Residence}

The reservation group was required to have lived on the reservation since birth. The urban group was required to have parents who had lived in the city since age two in order to eliminate as much assoc1ation with the reservation as possible. The White group was required to have lived in the city since birth.

\section{Indian Blood}

The reservation and urban groups were required to be 25 percent Blackfoot which is the percentage required for tribal enrollment. This percentage is determined by and varies with each reservation (Upham, 1977).

Speech, Hearing, and Physical Status

Each subject was judged to be normal in speech; hearing, and physical condition by the classroom teacher and school speech clinician.

\section{Instrumentation}

Screening for participation in the study and analysis of the data were based on the following instruments:

The Peabody Picture Vocabulary Test (PPVT) (Dunn, 1959) is a receptive picture vocabulary test composed of 150 plates or pages, each page containing four different simple black and white pictures. The examiner asks the child to point to one item on each page and marks the response either correct or incorrect on a record form. To establish 
basal the child must answer correctly eight items in a row; the ceiling is reached when the child misses six out of eight consecutively presented items.

The Developmental Sentence Score (DSS) (Lee, 1974) was developed to provide a quantitative measure of children's syntactic development in spontaneous speech. Eight grammatical-form categories are given developmentally weighted scores in addition to a score for a grammatically correct sentence. The grammatical-form categories which have been shown to have the most significant developmental progression in children's language are: indefinite pronoun or noun modifier; personal pronoun; main verb; secondary verb; negative; conjunction; interrogative reversal in questions; and wh-question (see Appendix B)

The Mean Length of Response (MLR) was introduced by Nice (1925) and has been used and refined in studies of language development by McCarthy (1930) and Templin (1957). It requires eliminating the first ten responses in a language sample and counting the number of words in fifty consecutive utterances (McCarthy, 1930). The number of words are totaled and divided by fifty (see Appendix C for a copy of MLR rules).

\section{Procedures}

\section{Test Administration}

Indian children are reported to be reluctant to talk with unfamiliar adults (McCluspey, 1977); therefore, prior to testing of the reservation group, the examiner spent time in the classroom talking, listening, and playing with the children., During the testing session for all groups, each subject was alone in a room with the examiner. 
The PPVT, Form A, was administered according to standard instructions provided by Dunn (1959). This test was administered to each child until the ceiling had been reached (see Appendix D for specific stimu1i).

A spontaneous language sample was obtained from subjects passing the criteria of the PPVT. The language sample was elicited untif the required responses were obtained from the subject. Sentences were considered complete when they expressed a subject-predicate relationship. The following procedural guide was utilized in obtaining the language sample: The language sample was obtained in the speech clinician's room in the child's school; toys, pictures, and illustrations were used to stimulate verbalization; open ended questions were used by the tester; the subject's verbalizations were repeated when possible to facilitate transcripțion of the sample and to induce further verbalization from the subject; all language samples were recorded using a Sony-Matic ree1-to-reel tape recorder, Mode1 TC-104A; the tape recording of each language sample was transcribed into a typed transcription by the investigator, who had received previous training in this task; the transcripts were analyzed for the use of the eight English grammatical rules by the DSS; and the same transcripts also were analyzed for MIR.

Scoring

DSS. Each typed transcript of the dialogue was tabulated for the Developmental Sentence Score (DSS) following the system devised by Lee (1974) in the DSS. In selecting the fifty sentences for grammatical analysis the procedure described by Lee (1974) was utilized (see 
Appendices $B$ and $E$ ).

MLR. Each typed transcript of the dialogues was tabulated for the MLR of the subject following a system patterned on or after McCarthy (1930). The total number of words used was divided by the fifty response units and this resulted in the child's MLR for that examination. The first ten utterances were not recorded as they are, on the average, shorter than the succeeding responses (McCarthy, 1930). Comparison to the norms and an inter-group analysis were conducted on the MLR results.

\section{Data Analysis}

Comparisons of the results of the MLR total scores, DSS total scores, and DSS item analysis of individual grammatical categories were made between the reservation, urban, and White groups. Mean scores and standard deviations were determined for the performance of each group, and the differences between the means of the three groups were analyzed, utilizing the t-test. 


\section{CHAPTER IV}

\section{RESULTS AND DISCUSSION}

\section{Results}

The present study sought to determine any differences in patterns of language usage among three groups of subjects. A language sample utilizing Mean Length of Response (MLR), Developmental Sentence Score (DSS), and individual DSS items was used to assess three groups of children: (1) urban Indian Group A; (2) reservation Indian Group B; and (3) control White Group C. There were a total of fifty utterances analyzed for each child (see Appendices F, G, and H for a language sample from each group and Appendices $I, J$, and $K$ for individual scores for each child).

The first question to be answered for the investigation was:

Does a comparison of urban White children (Group C) and urban Indian children (Group A) yield a significant difference in syntactical language development? If so, in what ways? Comparison of MLR (Table I) between the two populations revealed a mean MLR of 7.03 for Group $C$ and 6.43 for Group A. Results of $\underline{t}$-test analysis indicated a higher level of syntactical language development as measured by MLR for the urban White group, which was significant at the .025 level of confidence. Comparison of the DSS scores (Table II) revealed a mean DSS score of 9.37 for Group $C$ and 7.52 for Group A. Results of t-test analysis indicated a higher level of syntactical language development 
TABLE I

COMPARISON OF MLR SCORES

\begin{tabular}{lllll}
\hline Group & Mean & S.D. & df & $\underline{t}$ \\
\hline $\begin{array}{c}\text { Urban Indian } \\
\text { Group A } \\
\text { vs. }\end{array}$ & 6.43 & 0.80 & 24 & \\
$\begin{array}{c}\text { Reservation Indian } \\
\text { Group B } \\
\text { vs. }\end{array}$ & 6.08 & 0.75 & 24 & 1.151 \\
$\begin{array}{c}\text { Control White } \\
\text { Group C } \\
\text { vs. }\end{array}$ & 7.03 & 0.61 & 24 & $3.546 *$ \\
$\begin{array}{c}\text { Urban Indian } \\
\text { Group A }\end{array}$ & 6.43 & 0.80 & 24 & $2.154 *$ \\
\hline
\end{tabular}

*Significant at or $>.05$ leve1 of confidence

TABLE II

COMPARISON OF DSS SCORES

\begin{tabular}{lllll}
\hline Group & Mean & S.D. & df & $t$ \\
\hline $\begin{array}{c}\text { Urban Indian } \\
\text { Group A } \\
\text { vs. }\end{array}$ & 7.52 & 1.095 & 24 & \\
$\begin{array}{c}\text { Reservation Indian } \\
\text { Group B i } \\
\quad \text { vs. }\end{array}$ & 6.29 & 1.498 & 24 & $2.390 *$ \\
$\begin{array}{c}\text { Control. White } \\
\text { Group C } \\
\text { vs. }\end{array}$ & 9.37 & 1.540 & 24 & $5.169 *$ \\
$\begin{array}{c}\text { Urban Indian } \\
\text { Group A }\end{array}$ & 7.52 & 1.095 & 24 & $3.532 *$ \\
\hline
\end{tabular}

*Significant at or $>.05$ level of confidence 
as measured by the DSS for the urban White group, which was significant at the .005 level of confidence.

The second question posed was:

Does a comparison of urban Indian children (Group A) and reservation Indian children (Group B) yield a significant difference in syntactical language development? If so, in what ways? Comparison of MLR (Table I) between the two populations revealed a mean MLR of 6.43 for Group $A$ and 6.08 for Group B. Results of $\underline{t}$-test analysis indicated no statistically significant difference between urban and reservation Indian children; however, a trend toward significance was evidenced with urban Indian children displaying higher scores than reservation Indian children. Comparison of the DSS scores (Table II) revealed a mean DSS score of 7.52 for Group A and 6.29 for Group B. Results of t-test analysis indicated a higher level of syntactical language development as measured by the DSS for the urban Indian group, which was significant at the .025 level of confidence.

The third question was:

Does a comparison of urban White children (Group C) and reservation Indian children, (Group B) yield a significant difference in syntactical language development? If so, in what ways? Comparison of MLR (Table I) between the two populations revealed a mean MLR of 7.03 for Group C and 6.08 for Group B. Results of t-test analysis indicated a higher level of syntactical language development as measured by MLR for the urban White group, which was significant at the .005 leve1 of confidence. Comparison of the DSS scores (Table II) revealed a mean DSS score of 9.37 for Group C and 6.29 for Group B. Results of t-test 
analysis indicated a higher level of syntactical language development as measured by the DSS for the urban White group, which was significant at the .0005 level of confidence.

\section{Analysis of Individual DSS Items}

Due to the significant differences in the MLR and DSS scores it was necessary to determine the way in which the three groups differed in syntactical language development. An analysis of each of the eight grammatical forms and the sentence point used to determine the DSS was conducted.

Indefinite Pronoun. Computation of indefinite pronoun scores (Table III) revealed' a mean score of 45.00 for Group A, 48.54 for Group $B$, and 60.54 for Group C. The t-test analysis indicated the following results: a higher level indefinite pronoun development, which was significant at the .025 level of confidence, for Group $C$ when compared to Group A; no significant difference between Groups A and B; and no significant difference between Groups $C$ and $B$.

Personal Pronoun. Computation of personal pronoun scores (Table IV) revealed a mean score of 100.15 for Group A, 87.62 for Group B, and 112.38 for Group C. The t-test analysis indicated the following results: no significant difference between Groups $C$ and $A$; no significant difference between Groups $A$ and $B$; and $a$ higher level personal pronoun development, which was significant at the .005 level of confidence, for Group C when compared to Group B.

Main Verb. Computation of main verb scores (Table V) revealed a mean score of 84.77 for Group A, 69.85 for Group B, and 117.77 for Group $C$. The t-test analysis indicated the following results: a 
TABLE III

COMPARISON OF INDEFINITE PRONOUN SCORES

\begin{tabular}{lllll}
\hline Group & Mean & S.D. & df & t \\
\hline $\begin{array}{c}\text { Urban Indian } \\
\text { Group A } \\
\text { vs. }\end{array}$ & 45.00 & 18.63 & 24 & \\
$\begin{array}{c}\text { Reservation Indian } \\
\text { Group B } \\
\text { vs , White }\end{array}$ & 48.54 & 26.38 & 24 & 0.40 \\
$\begin{array}{c}\text { Control Wh } \\
\text { Group C } \\
\text { vs. }\end{array}$ & 60.54 & 18.28 & 24 & 1.38 \\
$\begin{array}{c}\text { Urban Indian } \\
\text { Group A }\end{array}$ & 45.00 & 18.63 & 24 & $2.19 *$ \\
\hline
\end{tabular}

*Significant at or $>.05$ level of confidence

TABLE IV

COMPARISON OF PERSONAL PRONOUN SCORES

\begin{tabular}{lllll}
\hline \multicolumn{1}{c}{ Group } & Mean & S.D. & df & t \\
\hline $\begin{array}{c}\text { Urban Indian } \\
\text { Group A } \\
\quad \text { vs. }\end{array}$ & 100.15 & 19.33 & 24 & \\
$\begin{array}{c}\text { Reservation Indian } \\
\text { Group B } \\
\text { vs. }\end{array}$ & 87.62 & 18.61 & 24 & 1.69 \\
$\begin{array}{c}\text { Control White } \\
\text { Group C : } \\
\quad \text { vs. }\end{array}$ & 112.38 & 23.50 & 24 & $2.98 *$ \\
$\begin{array}{c}\text { Urban Indian } \\
\text { Group A }\end{array}$ & 100.15 & 19.33 & 24 & 1.45 \\
\hline
\end{tabular}

*Significant at or $>.05$ level of confidence 
higher level main verb development, which was significant at the .0005 level of confidence, for Group C when compared to Group A; a higher level main verb development, which was significant at the .05 level of confidence, for Group A when compared to Group B; and a higher level main verb development, which was significant at the .0005 level of confidence, for Group C' when compared to Group B.

TABLE V

COMPARISON OF MAIN VERB SCORES

\begin{tabular}{lllll}
\hline Group & Mean & S.D. & df & $t$ \\
\hline $\begin{array}{c}\text { Urban Indian } \\
\text { Group A } \\
\quad \text { vs. }\end{array}$ & 84.77 & 18.20 & 24 & \\
$\begin{array}{c}\text { Reservation Indian } \\
\text { Group B : } \\
\text { vs. }\end{array}$ & 69.85 & 21.88 & 24 & $1.89 *$ \\
$\begin{array}{c}\text { Control White } \\
\text { Group C } \\
\text { v8. }\end{array}$ & 117.77 & 23.89 & 24 & $3.33 *$ \\
$\begin{array}{c}\text { Urban Indian } \\
\text { Group A }\end{array}$ & 84.77 & 18.20 & 24 & \\
\hline
\end{tabular}

* Significant at or $>.05$ leve 1 of confidence

Secondary Verb. Computation of secondary verb scores (Table VI) revealed a mean score of 17.46 for Group A, 16.54 for Group B, and 17.54 for Group $C$. The $t$-test analysis indicated the following results: no significant difference between Groups $C$ and $A$; no significant difference between Groups $A$ and $B$; and no significant difference between Groups $\mathrm{C}$ and $\mathrm{B}$.

Negative. Computation of negative scores (Table VII) revealed a 
TABLE VI

COMPARISON OF SECONDARY VERB SCORES

\begin{tabular}{lllll}
\hline Group & Mean & S.D. & df & $t$ \\
\hline $\begin{array}{c}\text { Urban Indian } \\
\text { Group A } \\
\quad \text { vs. }\end{array}$ & 17.46 & 7.37 & 24 & \\
$\begin{array}{c}\text { Reservation Indian } \\
\text { Group B } \\
\text { vs. }\end{array}$ & 16.54 & 11.33 & 24 & 0.25 \\
$\begin{array}{c}\text { Control White } \\
\text { Group C } \\
\text { vs. }\end{array}$ & 17.54 & 9.89 & 24 & 0.24 \\
$\begin{array}{c}\text { Urban Indian } \\
\text { Group A }\end{array}$ & 17.46 & 7.37 & 24 & 0.02 \\
\hline
\end{tabular}

*Significant at or $>.05$ level of confidence

TABLE VII

COMPARISON OF NEGATIVE SCORES

\begin{tabular}{lllll}
\hline Group & Mean & S.D. & df & $t$ \\
\hline $\begin{array}{c}\text { Urban Indian } \\
\text { Group A } \\
\text { vs. }\end{array}$ & 12.77 & 13.58 & 24 & \\
$\begin{array}{c}\text { Reservation Indian } \\
\text { Group B ! } \\
\text { vs. }\end{array}$ & 6.69 & 5.19 & 24 & 1.51 \\
$\begin{array}{c}\text { Control White } \\
\text { Group C } \\
\text { vs. }\end{array}$ & 20.31 & 17.17 & 24 & $2.74 *$ \\
$\begin{array}{c}\text { Urban Indian } \\
\text { Group A }\end{array}$ & 12.77 & 13.58 & 24 & 1.25 \\
\hline
\end{tabular}

*Significant at or $>.05$ level of confidence 
mean score of 12.77 for Group A, 6.69 for Group B, and 20.31 for Group C. The t-test analysis indicated the following results: no significant difference between Groups $C$ and $A$; no significant difference between Groups A and B; and a higher level negative development, which was significant at the .01 level of confidence, for Group $C$ when compared to Group B.

Conjunction. Computation of conjunction scores (Table VIII) revealed a mean score of 71.77 for Group A, 52.77 for Group B, and 94.00 for Group C. The t-test analysis indicated the following results: a higher level conjunction development, which was significant at the .01 level of confidence, for Group $C$ when compared to Group A; no significant difference between Groups $A$ and $B$, however, a trend toward a higher level conjunction development was indicated for Group

TABLE VIII

COMPARISON OF CONJUNCTION SCORES

\begin{tabular}{lllll}
\hline Group & Mean & S.D. & df & t \\
\hline $\begin{array}{c}\text { Urban Indian } \\
\text { Group A } \\
\quad \text { vs. }\end{array}$ & 71.77 & 31.31 & 24 & \\
$\begin{array}{c}\text { Reservation Indian } \\
\text { Group B } \\
\text { vs. }\end{array}$ & 52.77 & 30.35 & 24 & 1.57 \\
$\begin{array}{c}\text { Control White } \\
\text { Group C } \\
\quad \text { vs. }\end{array}$ & 94.00 & 24.00 & 24 & $3.84 *$ \\
$\begin{array}{c}\text { Urban Indian } \\
\text { Group A }\end{array}$ & 71.77 & 31.31 & 24 & \\
\hline
\end{tabular}

$*$ Significant at or $>.05$ level of confidence 
A; and a higher level conjunction development, which was significant at the .0005 level of confidence, for Group $C$ when compared to Group B. Interrogative Reversal. Computation of interrogative reversal scores (Table IX) revealed a mean score of 1.23 for Group A, 1.69 for Group B, and 1.46 for Group C. The t-test analysis indicated the following results: no significant difference between Groups $C$ and A; no significant difference between Groups $A$ and $B$; and no significant difference between Groups $C$ and $B$.

\section{TABLE IX}

COMPARISON OF' INTERROGATIVE REVERSAL SCORES

\begin{tabular}{lllll}
\hline Group & Mean & S.D. & df & t \\
\hline $\begin{array}{c}\text { Urban Indian } \\
\text { Group A } \\
\text { vs. . }\end{array}$ & 1.23 & 2.39 & 24 & \\
$\begin{array}{c}\text { Reservation Indian } \\
\text { Group B } \\
\text { vs. }\end{array}$ & 1.69 & 2.97 & 24 & 0.43 \\
$\begin{array}{c}\text { Contro1 White } \\
\text { Group C } \\
\text { vs. }\end{array}$ & 1.46 & 3.57 & 24 & 0.18 \\
$\begin{array}{c}\text { Urban Indian } \\
\text { Group A }\end{array}$ & 1.23 & 2.39 & 24 & \\
\hline
\end{tabular}

*Significant at or $>.05$ level of confidence

Wh-Question. Computation of wh-question scores (Table X) revea1ed a mean score of 1.46 for Group A, 1.23 for Group B, and 0.92 for Group $C$. The t-test analysis indicated the following results: no significant difference between Groups $C$ and $A$; no significant difference between Groups $A$ and, B; and no significant difference between Groups $C$ 
TABLE X

COMPARISON OF WH-QUESTION SCORES

\begin{tabular}{lllll}
\hline Group & Mean & S.D. & df & $t$ \\
\hline $\begin{array}{c}\text { Urban Indian } \\
\text { Group A } \\
\quad \text { vs. }\end{array}$ & 1.46 & 3.18 & 24 & \\
$\begin{array}{c}\text { Reservation Indian } \\
\text { Group B } \\
\text { vs. }\end{array}$ & 1.23 & 2.62 & 24 & 0.20 \\
$\begin{array}{c}\text { Control White } \\
\text { Group C } \\
\text { v8. }\end{array}$ & 0.92 & 1.55 & 24 & 0.37 \\
$\begin{array}{c}\text { Urban Indian } \\
\text { Group A }\end{array}$ & 1.46 & 3.18 & 24 & \\
\hline
\end{tabular}

*Significant at or $>.05$ level of confidence

and $B$.

Sentence Point. Computation of sentence point scores (Table XI) revealed a mean score of 36.77 for Group A, 30.38 for Group B, and 44.62 for Group C. The $t$-test analysis indicated the following results: a higher level sentence development, which was significant at the .0005 level of confidence, for Group C when compared to Group A; a higher level sentence development, which was significant at the .0005 level of confidence, for Group A when compared to Group B; and a higher level sentence development, which was significant at the .0005 level of confidence, for Group C when compared to Group B.

Although not tested, evaluation of the language samples revealed data not anticipated. Articulation errors, including a high incidence of vowel distortions, were noted and an unappropriate nasality was present. 
TABLE XI

COMPARISON OF SENTENCE POINT SCORES

\begin{tabular}{lllll}
\hline Group & Mean & S.D. & df & $t$ \\
\hline $\begin{array}{c}\text { Urban Indian } \\
\text { Group A } \\
\text { vs. }\end{array}$ & 36.77 & 4.25 & 24 & \\
$\begin{array}{c}\text { Reservation Indian } \\
\text { Group B } \\
\text { vs. W . }\end{array}$ & 30.38 & 4.19 & 24 & $3.86 *$ \\
$\begin{array}{c}\text { Contro1 White } \\
\text { Group C } \\
\text { vs. }\end{array}$ & 44.62 & 1.71 & 24 & $8.34 *$ \\
$\begin{array}{c}\text { Urban Indian } \\
\text { Group A }\end{array}$ & 36.77 & 4.25 & 24 & \\
\hline
\end{tabular}

*Significant at or $>.05$ level of confidence

\section{$\underline{\text { Discussion }}$}

The primary purpose of the study was to determine if there were any differences between three groups of first-grade children in syntactic language development utilizing as the measurement criteria Mean Length of Response (MLR), Developmental Sentence Score (DSS), and individual DSS items.

The first question sought to determine if the comparison of urban White and urban Indian children's language samples yielded a significant difference in syntactical language development. As shown in Tables I and II, results indicated a statistically significant difference with urban White children displaying higher scores for MLR and DSS (Figures 1 and 2). Urban White children also obtained significant1y higher scores on indefinite pronoun (Figure 3), main verb (Figure 4), 
MEAN LENGTH OF RESPONSE

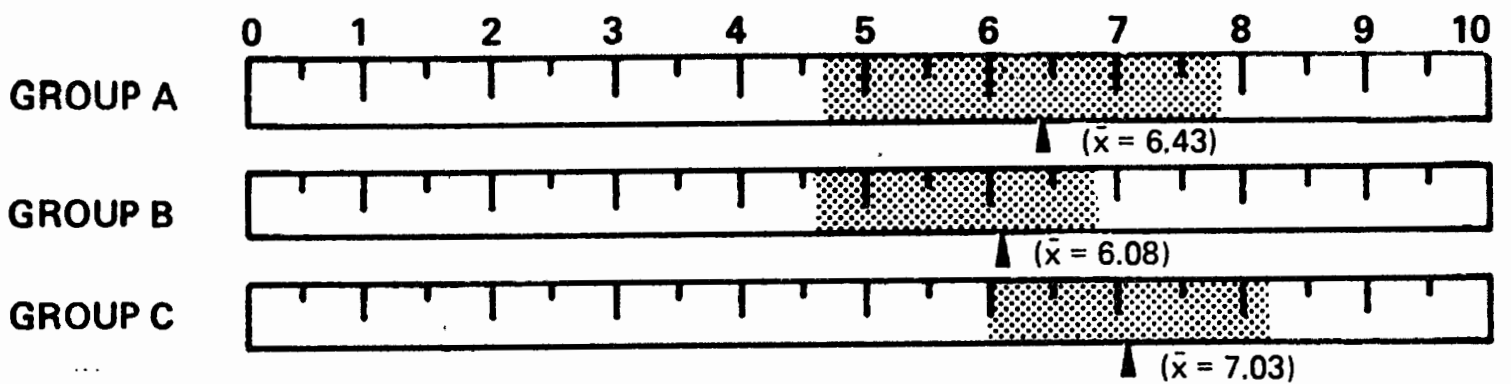

Figure 1. A comparison of the mean and range for MLR of each group.

DEVELOPMENTAL SENTENCE SCORE

GROUP A

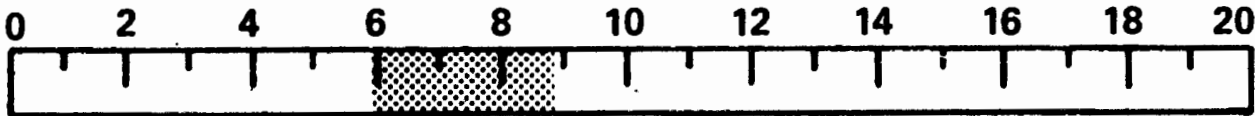

$1(\bar{x}=7.52)$

GROUP B

\begin{tabular}{|l|l|l|l|l|l|l|}
\hline 1 & 1 & 1 & 1
\end{tabular}

$(\bar{x}=6.29)$

GROUP C

\begin{tabular}{|l|l|l|l|l|l|l|l|}
\hline 1 & 1 & 1 & 1 & 1 & 1
\end{tabular}

(

Figure 2. A comparison of the mean and range for DSS of each group.

INDEFINITE PRONOUN SCORE

GROUP A

\begin{tabular}{|c|c|c|c|c|c|c|c|c|c|}
\hline 10 & 20 & 30 & 40 & 50 & 60 & 70 & 80 & 90 & 100 \\
\hline 11 & $\%$ & 8 & 8 & $8 \%$ & $\%$ & $\%$ & $T$ & $T$ & \\
\hline
\end{tabular}

$$
(\bar{x}=45.00)
$$

GROUP B

$(\bar{x}=48.54)$

GROUP C

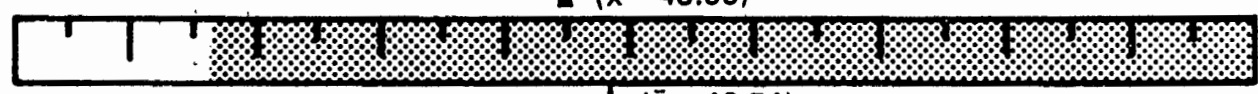

(n)

$(\bar{x}=60.54)$

Figure 3. A comparison of the mean and range for indefinite pronoun scores of each group. 
conjunction (Figure 5), and sentence point (Figure 6).

These data supported Mickelson and Galloway (1973) who observed differences between verbal concepts of Indian and White school children. It appeared the significant differences in their study were. associated with differing socioeconomic levels on cultural differences. The disparity in the language functions examined between the group of urban Indians and White children in the present study is particularly interesting since the students were literally sitting side by side in the same classroom receiving the same instruction. The difference in results may be due in part to the cultural background of the child and the degree in which the family preserves the Blackfoot culture. Those urban Indian children in this study attending the two schools saturated with Indian children obtained the lowest overall scores. This indicates that the more contact these Indian children have with whites the closer their language approaches that of the norms established for MLR and DSS. The present study tends to support the need, which is not currently being met, for individualized instruction based upon the child's initial language learning skills.

The second question sought to determine if a comparison of urban Indian and reservation Indian children's language samples yielded a significant difference in syntactical language development. Although there was a trend toward significance with urban Indian children obtaining higher scores, there was no significant difference between groups for the MLR score (Figure 1). It appears urban and reservation Indian children speak in similar sentence, lengths which may be due to cultural influence. These data support 0sborn (1973) who indicated 
MAIN VERB SCORE

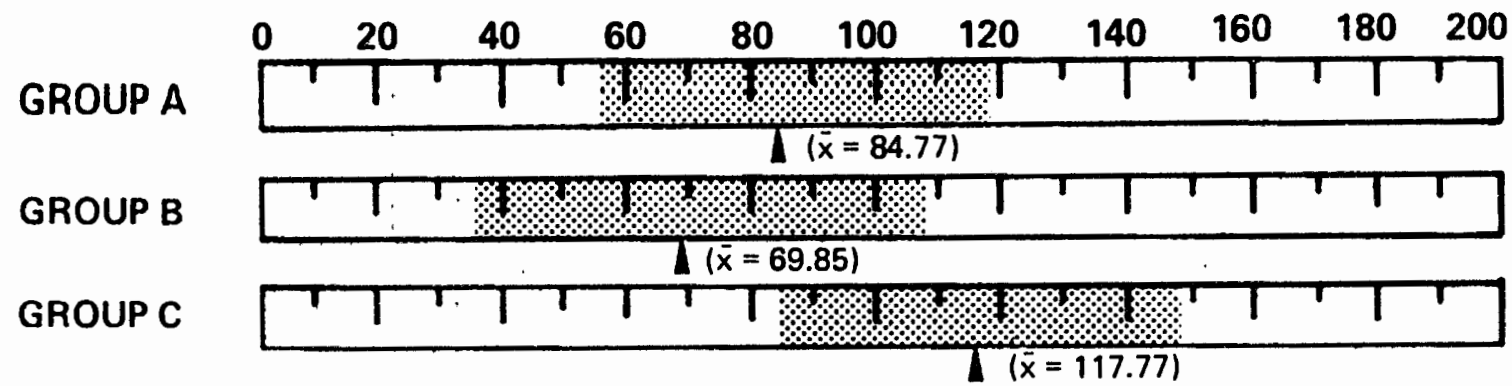

Figure 4. A comparison of the mean and range for main verb scores of each group.

CONJUNCTION SCORE

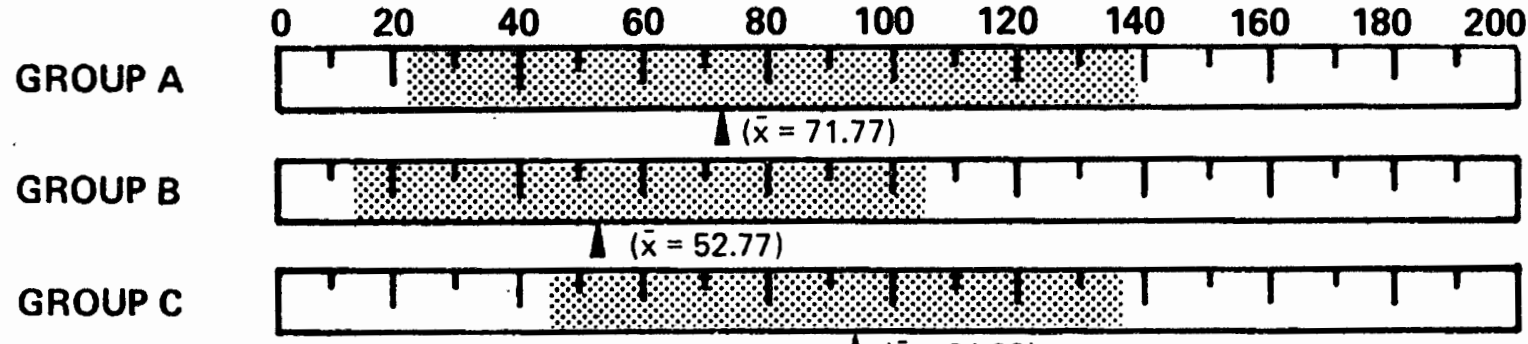

$$
(\bar{x}=94.00)
$$

Figure 5. A comparison of the mean and range for conjunction scores of each group.

SENTENCE POINT SCORE

GROUP A

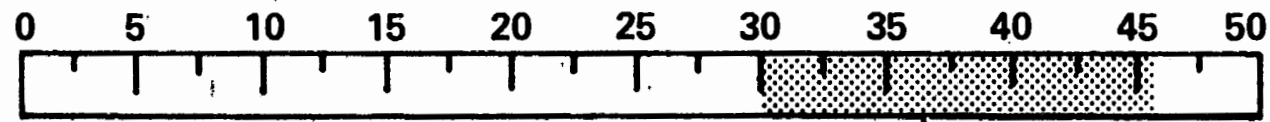

$$
1 \bar{x}=36.77)
$$

GROUP B

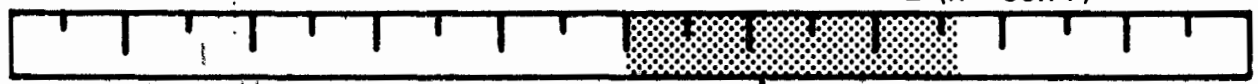

$(\bar{x}=30.38)$

GROUP C

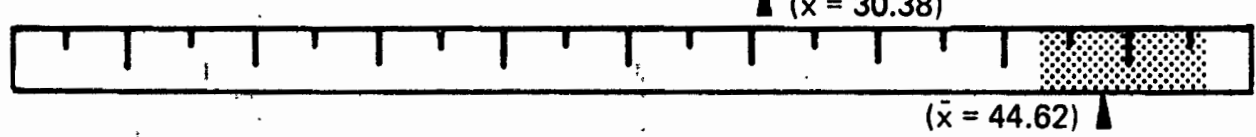

Figure 6. A comparison of the mean and range for sentence point scores of each group. 
most Indian children are taught to be seen, but not heard. Many urban Indians have relatives who live on the reservation and, therefore, continue to be exposed to the Blackfoot culture.

The DSS score (Figure 2 ) revealed a statistically significant difference between Indian groups, with urban Indian children obtaining higher scores. Although urban and reservation Indian children did not significantly differ on $\underline{\text { MLR, }}$, urban Indian children obtained significantly higher scores on main verb (Figure 4) and sentence point score (Figure 6). This may indicate that there is a tendency toward greater internal elaboration or sophistication on the part of the urban Indian child. Reservation Indian children used a basic grammatical relationship of the subject, verb, and object within a sentence, usually an agent-action semantic type, where the grammatical subject is the performer of some overt action. In analyzing the sentences the basic rules of subject, verb, and object order were not observed. Elaboration of the basic sentences was done using incorrect noun phrases and verb forms, which resulted in low sentence point scores for reservation Indians .

Based on this finding one might hypothesize, as the cultural environment of Indian children approaches that of White children in the public school, it appears the syntactical language development more closely approaches that of White students in the public school, than it does the Indian child's on the reservation. This is demonstrated particularly in a greater number of correct noun and verb elaborations and conjunctions, and a greater number of sentences appropriately word ordered. 
The third question compared urban White children to reservation Indian children in order to determine if there was a significant difference in syntactical language development. Results indicated a statistically significant difference between the groups for both MLR (Figure 1) and DSS (Figure 2) with urban White children obtaining higher scores than reservation Indian children.

Urban White children also obtained significantly higher scores on main verb (Figure 4); conjunction (Figure 5), sentence point (Figure 6), personal pronoun (Figure 7), and negative (Figure 8). These results indicate the language typically spoken in the home of culturally disadvantaged children has a tendency to be poor in context and verbal expression. These findings support those of Branchard (1953), Rist (1961), and Mizẹn (1966) who attribute the low performance of Indian children to their home environment. Many of the children on the Blackfoot reservation live at a different relative's home every two weeks, have one or two unemployed and alcoholic parents, and are absent a great deal from school. A frequent complaint is lack of communication between home and school.

The children involved in this study were among the highest in syntactic and educational development in the first-grade classrooms on the reservation. Due to the small number of clinicians to serve the reservation schools an Indian child must exhibit at least a three-year language delay in order to be eligible for speech and language services. The relatively poor results of the upper percent of reservation children indicate a need for service for all the children on the reservation. 


\section{PERSONAL PRONOUN SCORE}

GROUP A

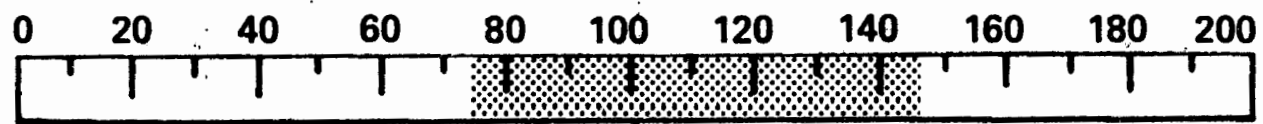
\rceil$(\bar{x}=100.54)$

GROUP B

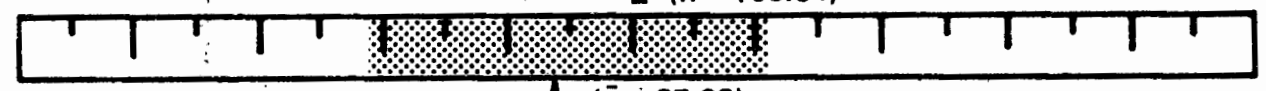
$(\bar{x}=87.62)$

GROUP C

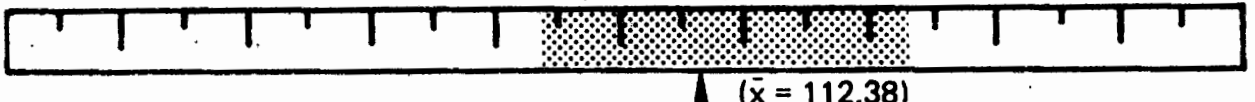

Figure 7. A comparison of the mean and range for personal pronoun scores of each group.

\section{NEGATIVE SCORE}

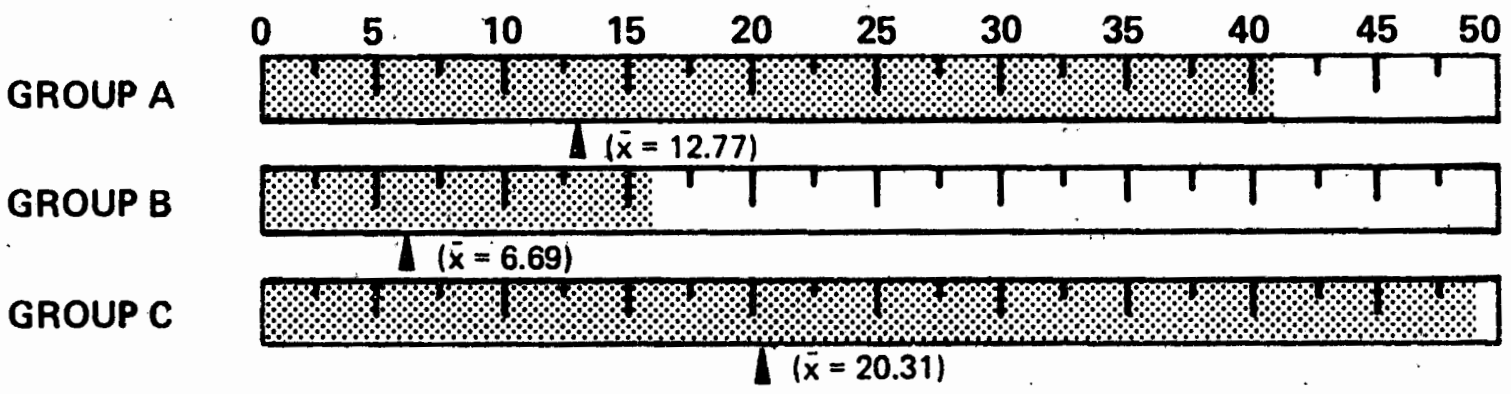

Figure 8. A comparison of the mean and range for negative scores of each group.

\section{SECONDARY VERB SCORE}

GROUP A

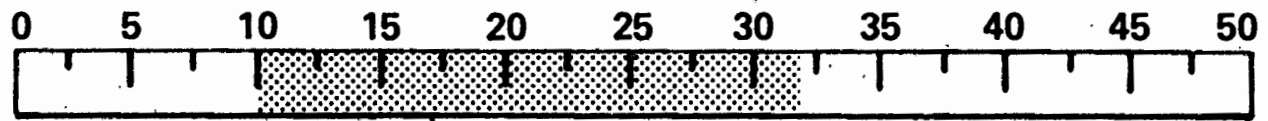

$$
\text { ( } \bar{x}=17.46)
$$

GROUP B

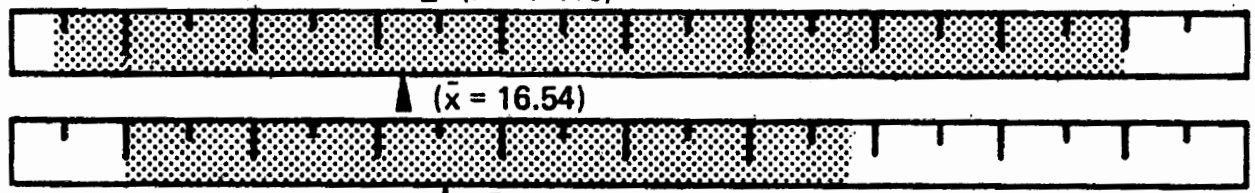

$$
(\bar{x}=17.54)
$$

Figure 9. A comparison of the mean and range for secondary verb scores of each group. 
These results also may be due in part to the limited number of appropriate language mode1s on the reservation. A small number of hospital employees and teachers constitute the models, but none live on the reservation.

Individual DSS item scores were compared for possible statistical significance. As shown in Tables III to XI, three items appeared to separate the groups: main verb (Figure 4); conjunction (Figure 5); and sentence point (Figure 6). Reservation Indian children obtained significally lower scores due to the use of more uninflected verbs; greater use of earlier developing conjunctions; omitted and confused a larger number of articles and prepositions; demonstrated the use of more unconventional plural and possessive markers; had more word order changes; and as a result obtained a lower sentence point score than the other two groups. Strong cultural identification and lack of appropriate language models contribute to these deficits.

Urban Indian children also obtained significantly lower scores than urban White children on main verb (Figure 4), conjunction (Figure 5), and sentence point (Figure 6). Although their contact with urban Whites appears to have increased the urban Indian's syntactic development, the variation in scores suggests the degree of cultural influence affects language development.

All subjects appeared to demonstrate a deficit when compared to DSS norms in the use of secondary verb (Figure 9), interrogative reversal (Figure 10), and wh-question (Figure 11 ). These results may have been due, in part, to the DSS evaluation and/or to the structure of the environment for eliciting the language sample. An attempt was made to 
INTERROGATIVE REVERSAL SCORE

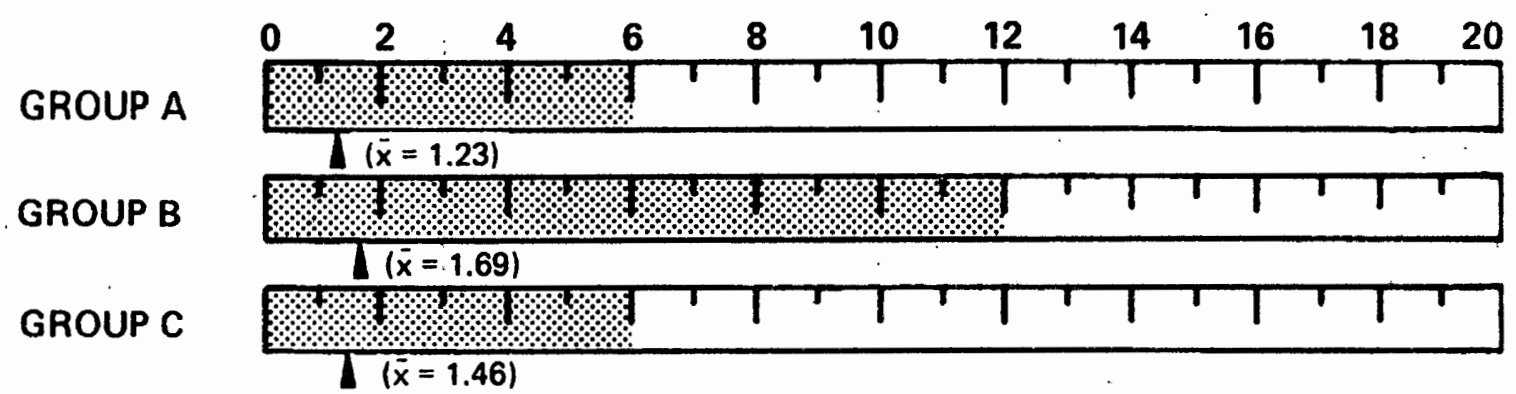

Figure 10. A comparison of the mean and range for interrogative reversal scores of each group.

\section{WH-QUESTION SCORE}

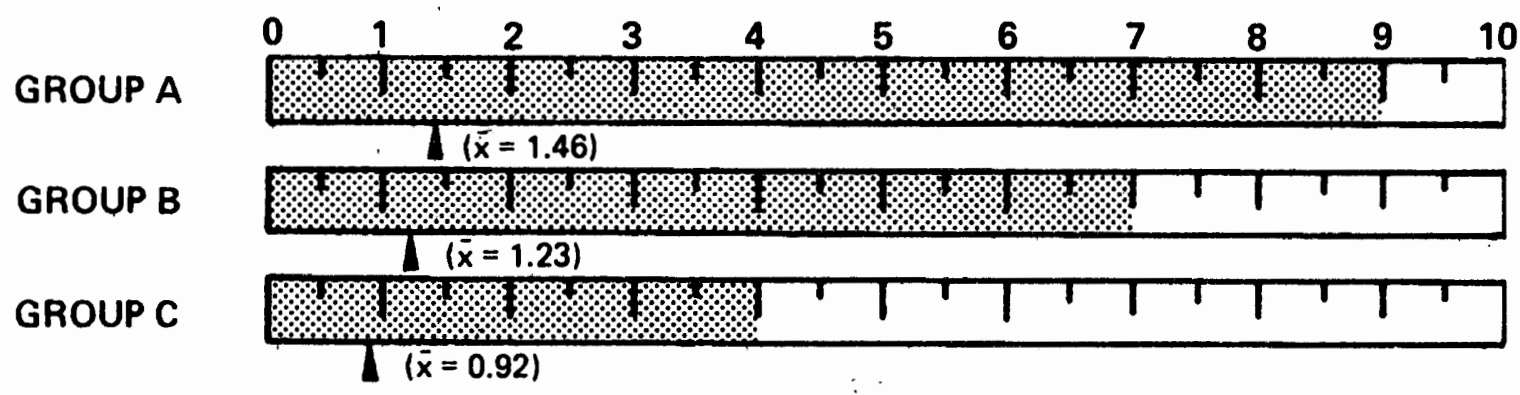

Figure 11. A comparison of the mean and range for wh-question scores of each group. 
elicit wh-questions in particular, but according to Lee (1974) they appear somewhat later in children's speech than do the other items. It appears pronouns, verb elaborations, simple negatives, and interrogative reversals begin development slightly ahead of secondary verbs (Lee, 1974). Due to the fact the language sample was not constructed to elicit a yes-no response or interrogative reversal, this may be the reason these scores appeared below the norms.

Figures 12 and 13 display individual scores for each group as compared to $M L R$ and DSS norms and the variation within these groups. Lee's (1974) normative data were based on two hundred subjects from upper middle-income families, which may explain the various scores of the urban White children.

Two possible explanations are indicated for the classroom language problems of Indian children: They have acquired less language than the middle-class child; or they have acquired a different language. Within the educational framework there is a lack of focus on communication competence. Based upon the data collected from this study it would be interesting to note if a change in the urban and reservation education policy would benefit the Indian child. At the present time there is little or no effort to devise individual language programs for the urban Indian child. Both reservation and urban school districts make few attempts to coordinate interaction between home and school for this age child. The limited number of social workers are involved with junior and senior high age students and their families rather than working with the younger child. It appears the present system is not alleviating the high dropout rate for these children. 

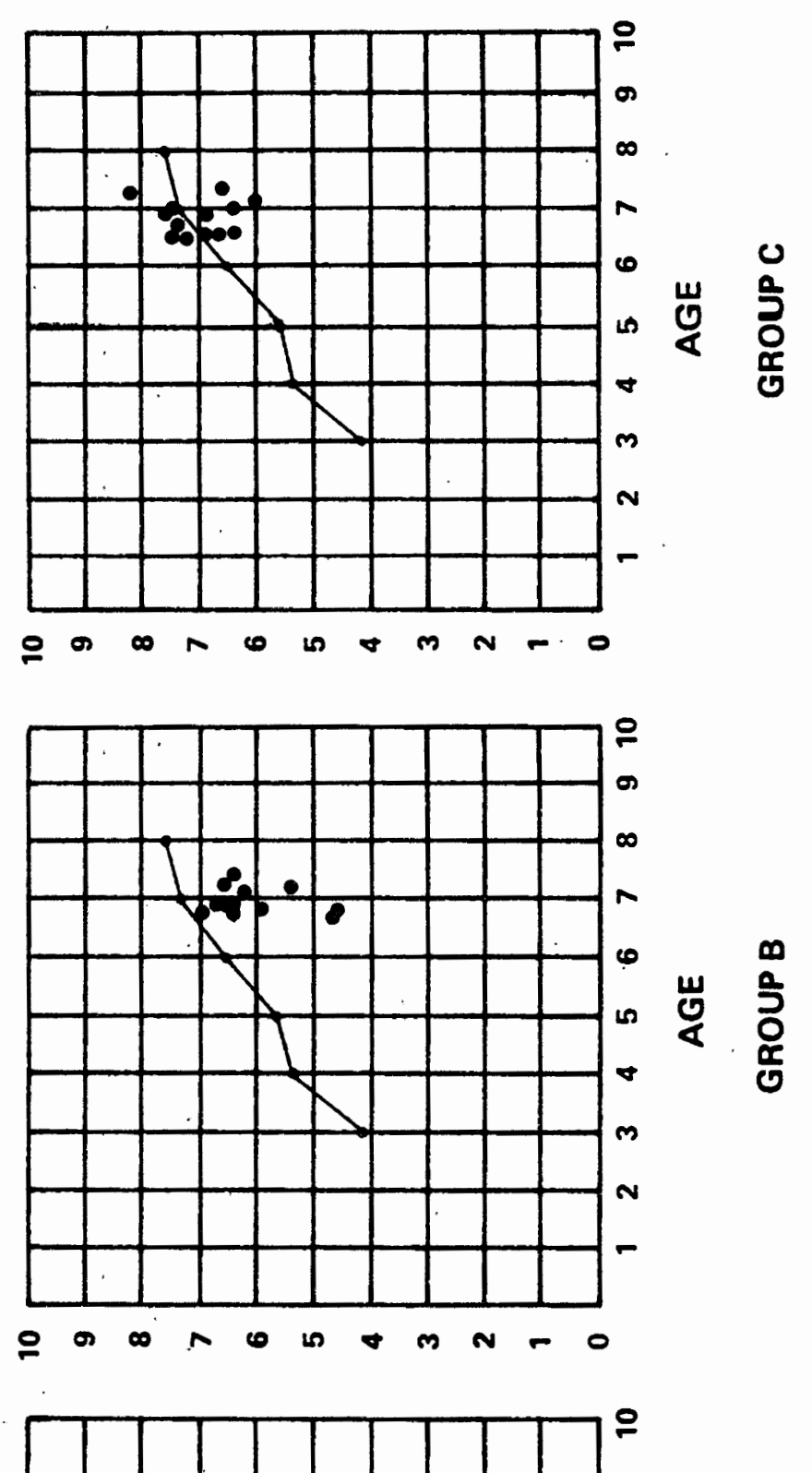

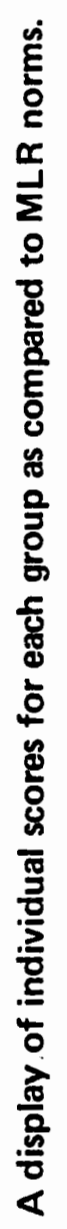

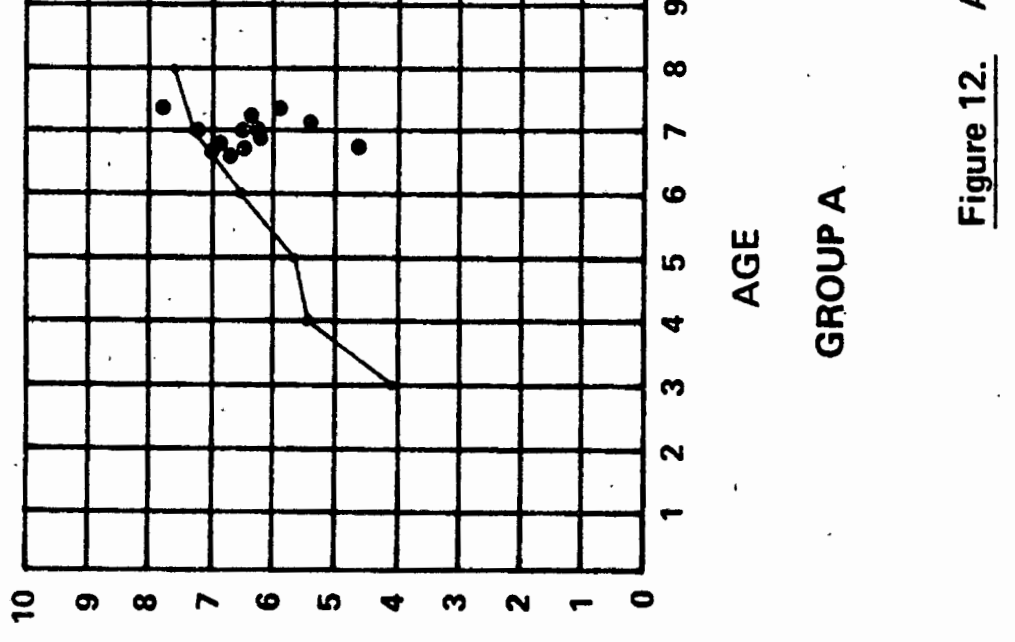




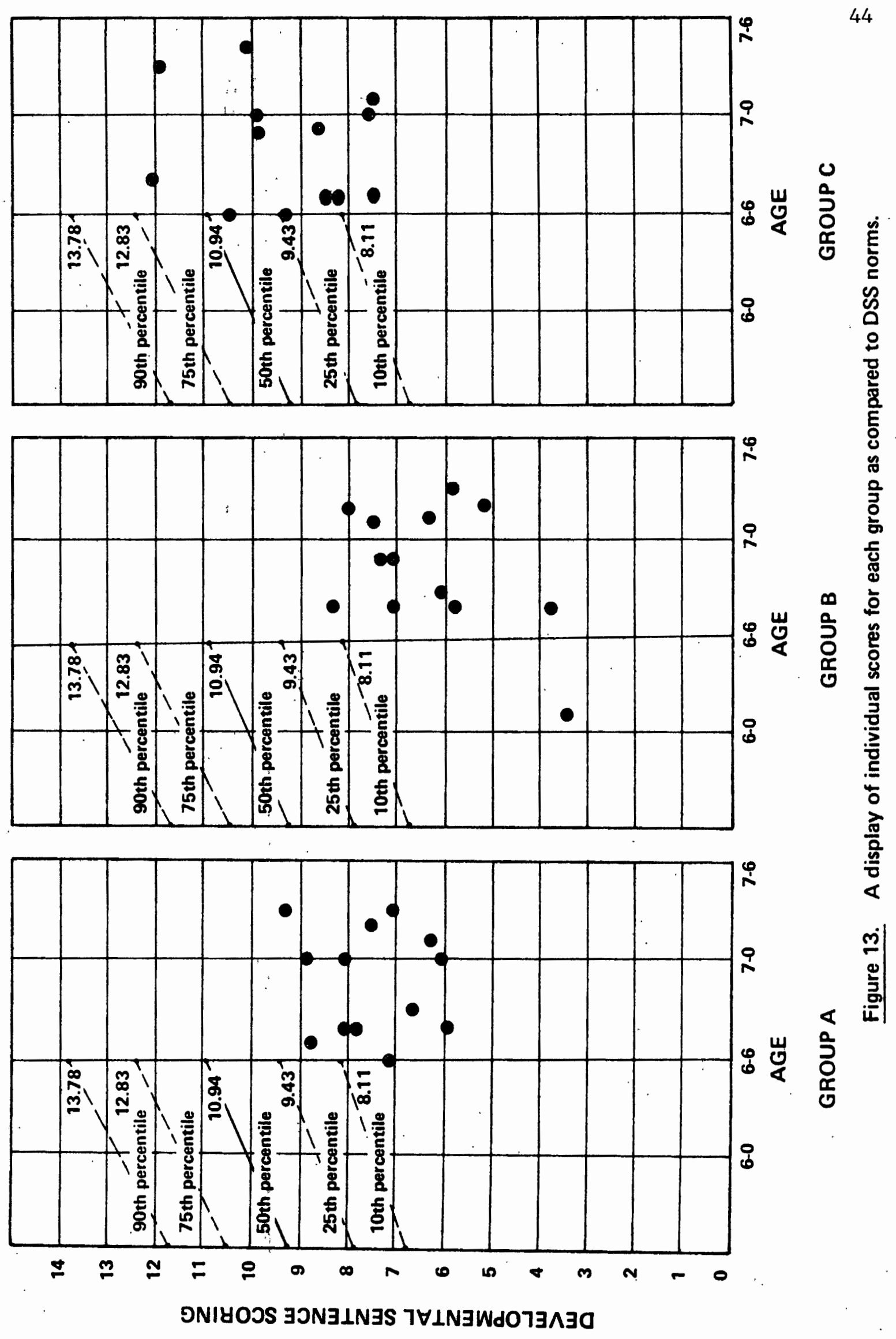


The school is applying an intensive home-school coordination effort after a problem has presented itself, rather than stressing prevention of language problems: 
CHAPTER V

SUMMARY AND IMPLICATIONS

\section{Summary}

This study sought to determine if there are any differences in an analysis of language samples between urban Indian, reservation Indian, and urban White first-grade children. The Mean Length of Response (MLR) (Temp1in, 1957), Developmental Sentence Score (DSS) (Lee, 1974), and individual DSS items were used to analyze language used by the three groups of children. The study involved thirty-nine children, thirteen children in each group, between the ages of six years, six months, and seven years, four months. All subjects were screened to determine grade, residency, Indian blood, speech, language, hearing, and physical status. Testing for hearing vocabulary was performed at the beginning of the testing situation to determine eligibility for the study.

The study was designed to determine whether there was a significant difference in syntactical language development between the groups as measured by $\underline{M R}, \underline{D S S}$, and the eight grammatical forms and sentence point from the DSS.

Results of the study indicate urban White children obtained significantly higher scores on $\underline{M R}$ and DSS than either reservation or urban Indian children. Urban Indian children obtained significantly higher scores on DSS than reservation Indian children. No statistical 
significant difference was noted between urban and reservation Indian children on $\underline{M L R}$; however, a trend toward significance was evidenced with urban Indian children displaying higher scores than reservation Indian children.

Results of individual DSS items indicated urban White children obtained significantly higher scores on indefinite pronoun, main verb, conjunction, and sentence point compared to urban Indian children. Urban White children also obtained significantly higher scores on personal pronoun, main verb, negative, conjunction, and sentence point compared to reservation Indian children. Urban Indian children obtained significantly higher scores on main verb and sentence point when compared to reservation Indian children.

The results of this study appear to indicate a positive correlation between a child's syntactical language development and his environment, which may be influenced by culture.

\section{Implications for Clinic and Future Research}

Clinic

The results of this study appear to indicate that DSS can be a useful tool in planning strategies in a language program for both urban and reservation Indian children. A clinical procedure for presentation of linguistic patterning or grammatical structure should be worked into a total language program for these children with particular emphasis on main verbs, conjunctions, negatives, secondary verbs, personal pronouns, individual pronouns, and grammatically correct use of sentences. A language program for urban and reservation Indian children could be 
an integral part of existing Head Start and kindergarten classes.

It appears obvious that Indian children will be confronted with a cultural conflict when they begin to associate with peer groups and teachers in the classroom. The design of a language program should be coordinated with information on the child's home environment. The Indian child's home life differs in degree from one to another and at present there is virtually no contact between the school and the home. A language program would be facilitated if the clinician were aware of the obstacles a child was confronting at home such as: language model, alcoholism, neglect, living conditions, and motivation.

Because the early part of a child's development takes place in the home, an Indian child is apt to absorb basic cultural values before entering the classroom. As part of the language program, early parent education should begin by working with the cultural language expectations of that child in the process of introducing new and more elaborate expectations. If a clinician ignores the cultural background, the Indian child may experience unnecessary difficulty and fail scholastically. Reports indicate an average 50 percent dropout rate (Misiaszek, 1969).

A necessary consideration of the language program would be that of an appropriate language model. The Browning Reservation, which was utilized in this study, employs few Whites and none live in the town or on the reservation. A concentrated effort to expose the children to television and/or appropriate language models is a prerequisite to the language program. There is an apparent need for more speech and language clinicians on the reservation and in the city. This need will 
not be met in the immediate future so a joint effort of clinician, teacher, parent, and administration is required if the Indian child is to function at a higher level outside his/her immediate environment. The urban Indian children in this study are presently concentrated in two schools and desegregation may aid this effort.

\section{$\underline{\text { Research }}$}

This investigator suggests a replication of this study utilizing $\underline{M L R}$ and DSS with modifications. Inclusion of a test in visual memory is indicated. The teachers and clinicians on the reservation reported the reservation and urban Indian children perform better on spelling and reading than other academic subjects. Results of this type of research might indicate the inclusion of visual activities in a language program.

This investigator noted reluctance of the reservation Indian children to talk with adults. A modification utilizing several situations and various clinicians would yield more complete and accurate language samples. Techniques to motivate the Indian child to talk should be included to determine those most effective for use in clinical intervention.

When language samples for the present study were obtained, a vowel distortion was noted of many reservation and urban Indian children. A replication of the study should analyze the Blackfoot language, still spoken by some elders on the reservation, to determine the influence it may have on present articulation or vowel production.

A replication of the study involving various Indian tribes would indicate if the significant differences in this study's grammatical 
analysis could be generalized to other tribes.

Professionals educating the Blackfoot report a greater disparity from the norms as the children reach the fourth and fifth grades than is evident in the first grade. A replication at a different age level is indicated. 
SELECTED BIBLIOGRAPHY

ANASTASIOW, N., Educating the culturally different child. Viewpoints, 48, 21-42 (1972).

ANDERSON, K., The Educational Achievement of Indian Children. Washington, D.C.: 'Bureau of Indian Affairs (1953).

BARLOW, E., Blackfeet Indian Language. Montana: Browning Schools $(1973)$.

BERRY, B., The Education of American Indians: A Survey of the Literature. Washington, D.C.: U.S. Government Printing Office (1968).

BLOSSOM, G., A new approach to an old problem. J. of American Indian Education, 1, 17-19 (1962).

BOWD, A., Linguistic background and nonverbal intelligence: A cross cultural comparison. J. of Educ. Res., 68, 26-27 (September 1974).

BRANCHARD, R., A Comparative Study of the Intermediate Grades of Two Indian Schools and Two Public Schools in Rolette County. North Dakota: Univ : of North Dakota (1953).

CASDEN, C., and JOHN, V., Styles of Learning Among American Indians. Washington, D.C.: Bureau of Indian Affairs (August 1968).

COLEMAN, J., Equality of Educationa1 Opportunity. Washington, D.C.: U.S. Government Printing office (1966).

COOMBS, M., KRON, R., COLLISTER, E., and ANDERSON, K., The Indian Child Goes to School. Kansas: Haskell Press. (1958).

DEISSLER, K., A study of South Dakota Indian achievement problems. J. of American Indian Education, 3, 19-21 (1962).

DUFFY, D., Survey of Indians of Cascade County Montana. Great Falls: Opportunities Inc. (1972).

DUNN, L., Peabody Individual Achievement Test. Circle Pines, Minnesota: American Guidance Service (1959).

FELBER, R., Factors Influencing the Educational Attainments of Indian Pupils in South Dakota. Univ. of Wyoming (1955). 
FISCHLER, A., Education and social progress. Alberta J. of Educ. Res., $12,257-268$ (1966).

FRY, M., and JOHNSON, C., Oral language production and reading achievement among selected students. J. of American Indian Education, 13, 22-28 (October 1973).

FUCHS, E., and HAVIGHURST, R., To Live on This Earth: American Indian Education. Garden City, New York: Anchor Press (1973).

Great Falls School District, Personal Interviews, Great Falls, Montana (December 1977).

HARDY, W., Some biologic and social aspects of communicative problems. In W. G. Hardy, Communication and the Disadvantaged Child. Ba1timore: The Williams and Wilkins Company (1970).

HAVIGHURST, R., Environment and the Draw-A-Man Test: The Performance of Indian Children. J. of Abnormal and Social Psychology, 61 (1946).

HAVIGHURST, R., and HILKEVITCH, R., The intelligence of Indian children as measured by a performance scale. J. of Abnormal and Social Psychology, 39, 419-433 (October 1944).

HAWTHORN, H., A Survey of Contemporary Indians of Canada: Economic, Political, Educational Needs and Polícies. Ottawa: Queen's Printer (1967).

JOHN, V., Styles of learning-styles of teaching: Reflection on the education of Navajo children. Functions of Language in the Classroom, New York: Teachers College Press (1972).

LEE, L., Developmental Sentence Analysis. Evanston: Northwestern Univ. Press (1974).

IESSER, A., Education and future of tribalism in the United States: The case of the American Indian. Social Science Rev., 35, 333350 (1961).

McCARTHY, D., The Language Development of the Preschool Child. Minneapolis: Univ. of Minn. Press (1930).

McCLUSKEY, M., Personal Interview, Director Indian Affairs, Great Falls, Montana: (December 1977).

MICKELSON, N., and GALLOWAY, C., Cumulative language deficits among Indian children. Exceptional Children, 36, 187-190 (November 1969).

MICKELSON, N., and GALLOWAY, C., Verbal concepts of Indian and nonIndian school beginners. J. of Educ. Res., 67, 55-56 (October 1973). 
MILLER, H., Report of Indian Education in Montana. State Department of Pub1ic Instruction, Project No. 1:22, 11-4-63-200 (1962).

MISIASZEK, L., Cultural dilemma of American Indians. Social Educ., 33, 438-493 (1969):

MIZEN, H., Federal Facilities for Indians: Tribal Relations with the Federal Government. Washington, D.C.: U.S. Government Printing Office (1966).

National Study of American Indian Education: The Education of Indian Children and Youth, Project No. 8-0147. U.S. Office of Education, OEC-0-9-08147-2805 (1971).

NICE, M., Length of sentences as a criterion of a child's progress in speech. J. of Educational Psychology, 16, 370-379 (1925).

OLIVER, M., The development of language concepts of pre-primary Indian children. Language Arts, 52, 865-870 (1975).

OLIVER, S., and PETERSON, C., What Indians Think an Indian Is: A Study of Persona1 and Educational Attitudes. Master's Thesis, Portland State Univ. (1975).

OSBORN, L., Language, poverty, and the North American Indian. In F. Williams (Ed.), Language and Poverty: Perspective on a Theme. Chicago: Univ. of Chicago Press (1970).

OSBORN, L., Rhetoric, repetition, silence. J. of American Indian Educ., 12, 15-21 (January 1973).

PENOI, C., Some Factors of Academic Achievement in High School Pupils Attending Selected Indian Boarding Schools in Oklahoma. Ph.D., Univ. of Oklahoma (1956).

PETERSON, S., How We11 Are Indian Children Educated. Washington, D.C.: Bureau of Indian Affairs (1948).

PHILLIPS, S., Participant structures and communicative competence. Functions of Language in the Classroom. New York: Teachers College Press (1972).

PROVANCE, E., Problems of Teaching English in an Intercultural Boarding School for Eskimo and Indian Students. Master's Thesis, Fresno State College (1963).

RIST, S., Shoshone Indian Education: A Descriptive Study Based on Certain Influential Factors Affecting Academic Achievement of Shoshone Indian Students, Wind River Reservation, Wyoming. Master's Thẹsis, Montana State Univ. (1961). 
ROESSEL, R., Handbook for Indian Education. Arizona: Amerindian Pub1. Co. (1962).

ROHNER, R., Factors influencing the academic performance of Kwakiut 1 children in Canada. Comparative Educ. Rev., 9, 331-340 (October 1965).

SORKIN, A., American Indian and Federal Aid. Washington, D.C.: The Brookings Institute (1971).

TEMPLIN, M., Certain Language Skills in Children. Minneapolis: Univ. of Minnesota Press (1957).

TYLER, S., American Council on Education. Helping Teachers Understand Children, Washington, D.C.: Commission on Teacher Education, 8-20 (1945).

UPHAM, K., Personal Interview. Opportunities Inc., Great Falls, Montana (December 1977).

WASHBURN, W., Red Man's Land-White Man's Law. New York: Charles Scribner's Sons (1971).

ZINTZ, M., Education Across Cultures. Dubuque, Iowa: William C. Grown Co. (1963).

ZINTZ, M., Language difference and reading. Paper Presented at the annual meeting of the International Reading Association, ERIC (1976). 
APPENDIX A

PERMISSION REQUEST

\section{Dear Parent:}

I am a graduate student at Portland State University doing a research project with language development and Indian children. I have the approval of the school district, and with your permission I would like to administer a hearing vocabulary test and talk to your child at school for approximately one-half hour.

In no way will your child's name be used in this study. Will you please help me by signing the slip below and sending it to school with your child.

Thank you,

Lezlie Pearce

Graduate Student

Portland State University

Portland, Oregon

I give my permission for Lezlie Pearce to talk with my child. Child's name

Birthdate

Has the child lived on the reservation since birth? 
DEVELOPMENTAL SENTENCE SCORING

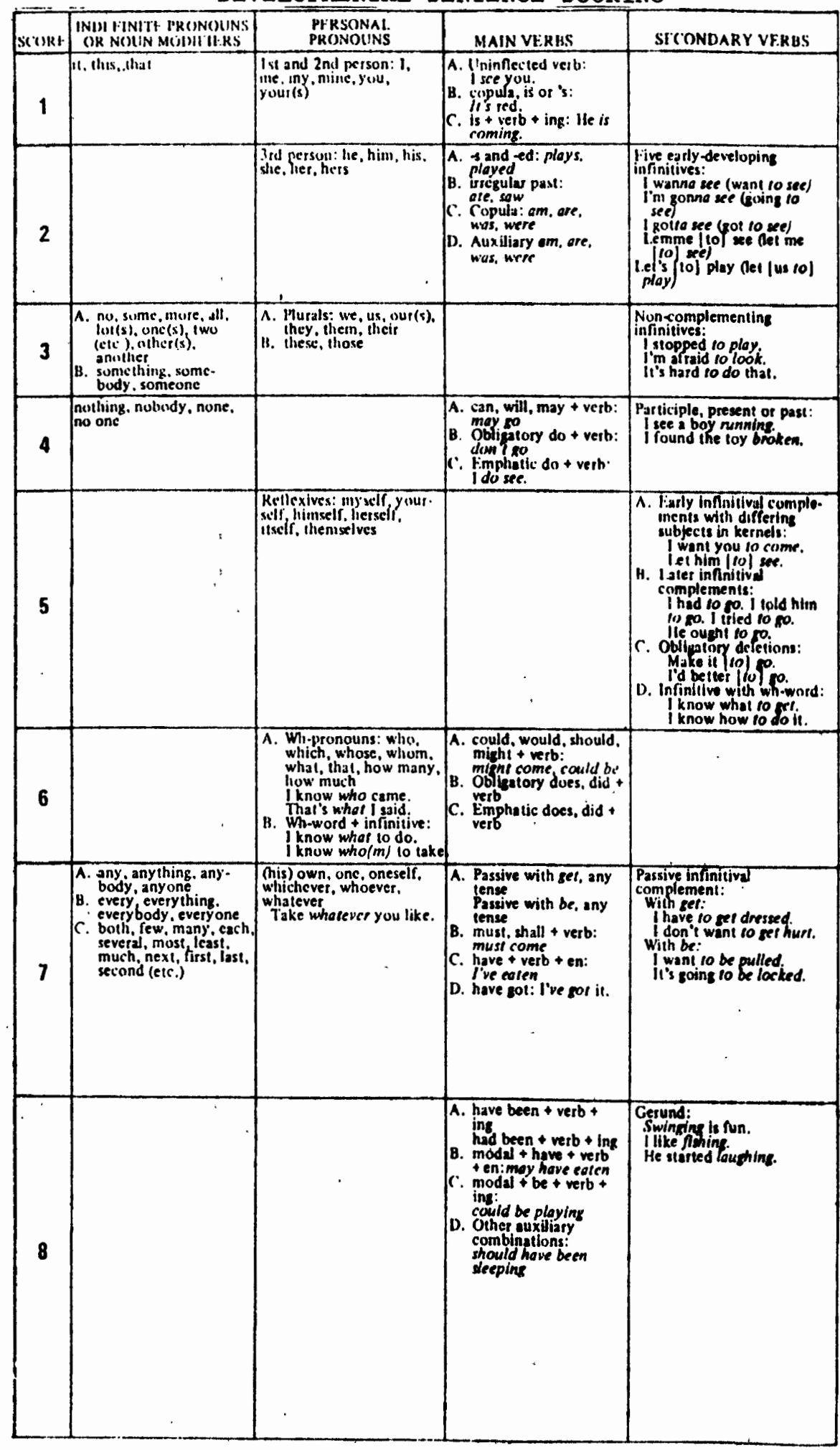




\begin{tabular}{|c|c|c|c|}
\hline Nl:CATIVIS & IONJINCTIONS & $\begin{array}{l}\text { INIFRROCATIVI: } \\
\text { KEVTKSAIS }\end{array}$ & WHTOULSTIONS \\
\hline \multirow[t]{3}{*}{ 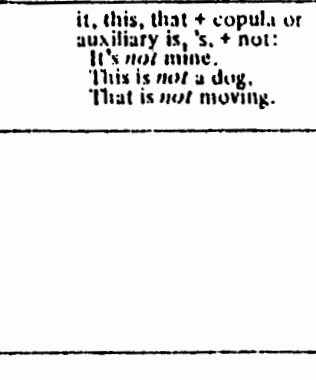 } & $\vdots$ & $\begin{array}{l}\text { Reversal of copula: } \\
\text { /sn'tif red? Were they } \\
\text { linere? }\end{array}$ & \\
\hline & 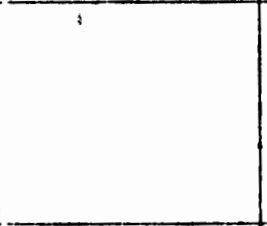 & & 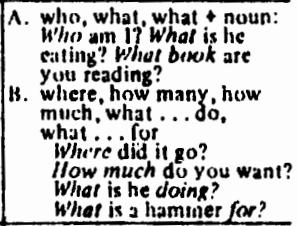 \\
\hline & ind & & \\
\hline ian't. don't & & $\begin{array}{l}\text { Reversal of auxiliary be: } \\
\text { Is he coming? lsn'the } \\
\text { couning? Wes he hoing? } \\
\text { Wasn'the guing? }\end{array}$ & \\
\hline \multirow[t]{2}{*}{ isn't, won't } & $\begin{array}{l}\text { A. but } \\
\text { is. and su, so that } \\
\text { or. if }\end{array}$ & & $\begin{array}{l}\text { when how how + adjective } \\
\text { Whin shall I come? } \\
\text { Whw do you do it? } \\
\text { IIow big is it? }\end{array}$ \\
\hline & becaust & 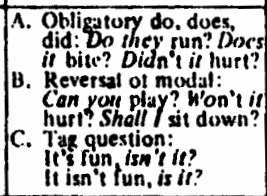 & 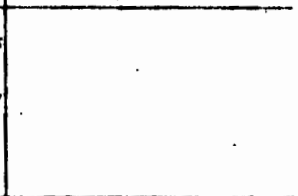 \\
\hline 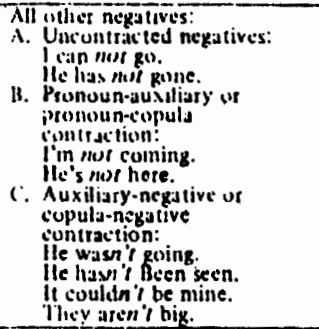 & . & tom- & 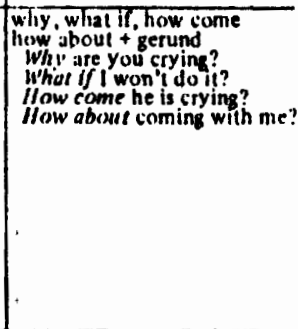 \\
\hline$\cdot$ & 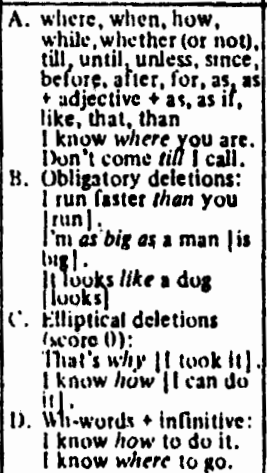 & 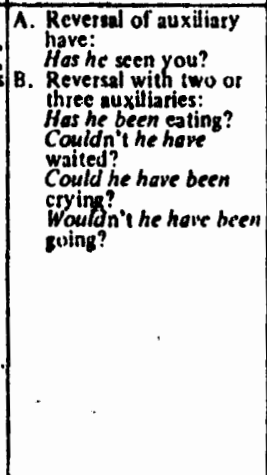 & $\begin{array}{l}\text { whore, which, which + noun } \\
\text { Whose car is hat? } \\
\text { which book do you want? }\end{array}$ \\
\hline
\end{tabular}


APPENDIX C

MLR RULES

The following standards, developed by McCarthy (1930) are used in determining how words should be counted.

1. Contractions of the subject and predicate like "it's" and "you're" are counted as two words.

2. Contractions of the verb and the negative like "can' $t$ " are counted as one word.

3. Hyphenated words and compound nouns, proper nouns that are not hyphenated but function as single words and as names of single objects, are counted as single words.

4. Each part of a verbal combination is counted as a separate word.

5. "Lookit" is counted as one word if it occurs alone and functions simply as "look"; if followed by an object, it is counted as the two words "look at."

6. Each of the following is to be counted as one word: oh boy, my gosh, darn it, doggone it, all right, maybe, giddy-up, someone, lighthouse, birdhouse, high school, ain't.

7. Each of the following is to be counted as two words: oh yes, oh no, oh gee, let's see, on to, Christmas tree, kinda, oughta, hafta.

8. Since repetitions can add substantially to the length of the uttered response, they should be excluded according to the following rules:

a. When the same word is repeated several times consecutively it should be counted only once.

b. When a phrase is repeated it should be counted. only once.

c. When a child repeats a word for enumerative purposes and for starting a new thought unit, he should not be penalized for repetition. 
9. Words not completed by the child should be recorded as though they were completed.

10. Noises should be counted only when they are considered to be an integral part of the sentence.

11. Interjections not considered dictionary items and functioning solely to connect words or phrases should not be counted: "er," "um," etc.

12. Al1 colloquialisms and neologisms should be counted. 
APPENDIX D

\section{PEABODY PICTURE VOCABULARY TEST \\ FORM A}

\begin{tabular}{|c|c|c|c|c|c|}
\hline $\begin{array}{l}\text { Plate } \\
\text { No. }\end{array}$ & Key Resp. Emors" & $\begin{array}{l}\text { Plate } \\
\text { No. }\end{array}$ & Key Resp. Errons" & $\begin{array}{l}\text { Plate } \\
\text { No. }\end{array}$ & Koy Rosp. E \\
\hline 1 & $\ldots \ldots \ldots(4)$ & 26 & teacher ..... (2) __ & 51 & submarine . . \\
\hline 2 & $\operatorname{cow} \ldots \ldots \ldots(3) \ldots[]$ & 27 & building $\ldots$. (3) & 52 & thermos ..... (4) \\
\hline 3 & baby $\ldots \ldots(1) \ldots$ & 28 & arrow ..... (3) & 53 & projector . . . (3) (3) \\
\hline 4 & girl $\ldots \ldots \ldots(2) \ldots\{$ & 29 & kangaroo .... (2) & 54 & group ...... (4) \\
\hline 5 & ball $\ldots \ldots \ldots(1) \_\nabla$ & 30 & accident $\ldots$. (3) & 55 & tackling ..... (3) \\
\hline 6 & block ....... (3) _ _ מ & 31 & nest $\ldots \ldots \ldots(3) \ldots$ & 56 & transportation (1) \\
\hline 7 & clown $\ldots \ldots \ldots(2) \ldots \diamond$ & 32 & caboose ... . (4) _ _ & 57 & counter ..... (1). \\
\hline 8 & key $\ldots \ldots \ldots(1) \ldots O$ & 33 & envelope $\ldots .(1) \_\checkmark$ & 58 & ceremony ... . (2)___ \\
\hline 9 & $\ldots \ldots \ldots(4) \_[]$ & 34 & picking $\ldots . .(2) \ldots$ & 59 & pod $\ldots . . .(3) \ldots$ \\
\hline 10 & chicken $\ldots . .(2) \_\Delta$ & 35 & badge $\ldots . . .(1) \_>$ & 60 & bronco ..... (4) ___ \\
\hline 11 & blowing ..... (4) _ & 36 & goggles ..... (3) _ & 61 & directing ... . (3) \\
\hline 12 & fan $\ldots \ldots \ldots(2)$ & 37 & peacock ..... (2) & 62 & \\
\hline 13 & digging $\ldots .$. (1)___ & 38 & queen $\ldots \ldots$ (3) & 63 & delight . \\
\hline 14 & skirt $\ldots \ldots \ldots(1)$ & 39 & coach $\ldots . .(4) \ldots$ & 64 & r.....(3) \\
\hline 15 & catching $\ldots .(4)$ & 40 & whip $\ldots \ldots$ (1) _.. & 65 & communication (2) \\
\hline 16 & drum $\ldots \ldots \ldots$ ( & 41 & net $\ldots \ldots \ldots(4) \ldots$ & 66 & archer ..... (4) _... \\
\hline 7 & leaf $\ldots \ldots \ldots$ (3)__ $\triangle$ & 42 & freckle ...... (4)__ $\diamond$ & 67 & $\ldots(1) \ldots$ \\
\hline 18 & tying ...... (4) _ _ & 43 & eagle $\ldots . . .$. (3)___ 0 & 68 & $\ldots(1)$ \\
\hline 19 & fence $\ldots . .$. (1) $\_\nabla$ & 44 & twist $\ldots \ldots \ldots(2) \_[C]$ & 69 & assaulting \\
\hline 20 & bat $\ldots \ldots \ldots(2) \ldots$ 泣 & 45 & shining $\ldots .$. (4) $\_\triangle$ & 70 & (1) \\
\hline 21 & bee $\ldots \ldots \ldots(4) \_\diamond$ & 46 & dial ....... (2)__f & 71 & meringue .... (1) \\
\hline 22 & bush $\ldots . \ldots(3) \ldots$ & 47 & yawning $\ldots . . .(2) \_\_$ & 72 & appliance $\ldots$ (3) \\
\hline 23 & pouring $\ldots . .(1) \ldots[\square$ & 48 & tumble ...... (2)__ is & 73 & chemist. \\
\hline 24 & sewing $\ldots \ldots(1) \ldots \triangle$ & 49 & signal $\ldots . \ldots(1) \_\oslash$ & 74 & $\ldots(3) \ldots$ \\
\hline 25 & wiener ..... (4) __ & 50 & capsule .....(1) _ & 75 & destruction .. (4) \\
\hline
\end{tabular}




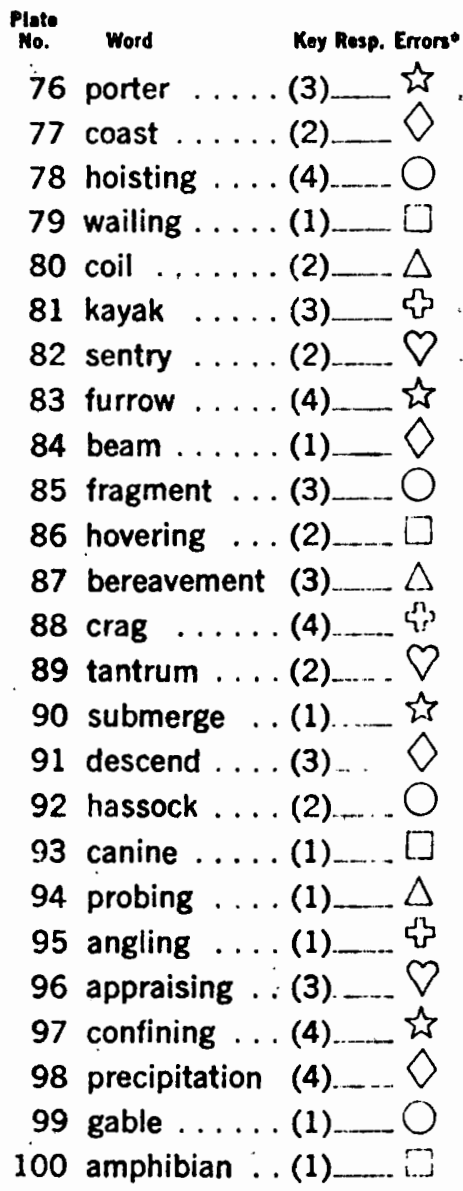

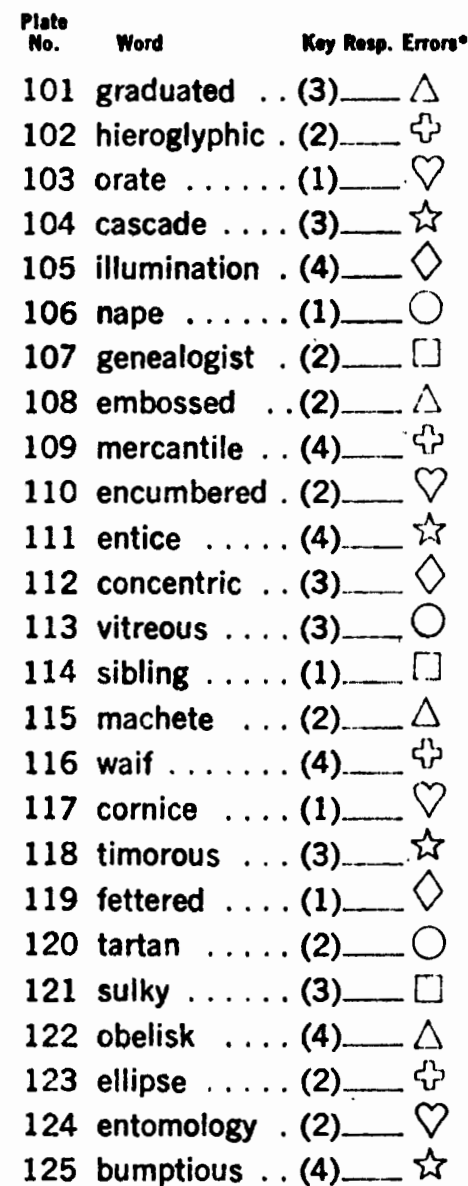




\section{APPENDIX E}

\section{DSS RULES}

The following procedures, developed by Lee (1974) are used to determine how sentences should be selected.

1. The sample should contain fifty complete sentences for analysis. A sentence is judged complete if it has. a noun and verb in subject-predicate relationship.

2. The speech sample must be a block of consecutive utterances.

3. Al1 utterances in a language sample must be different. No repetitions of sentences are to be included.

4. Unintelligible utterances should be excluded from the sample. Sentences should be counted if the grammatical structure is intelligible; however, if the unintelligible word involves a potentially scoring part of the utterance the whole utterance should be discarded.

5. Echoed utterances should be excluded from the sample. 
APPENDIX F

TYPICAL LANGUAGE SAMPLE URBAN INDIAN GROUP A

1. Ed's a little tiny guy

2. That's all I think

3. He just keeps on fighting me

4. I go play at my friend's

5. Who's little truck?

6 . When I was over in Shelby

7. Horses a whole bunch of them

8. We put them in barns

9. We were the first ones over there

10. We just went to go chase rabbits and went to go play

11. We went way up in the stands

12. You know where they sit and all that

13. There's a whole bunch of them

14. This time my horse is gonna win Showman Trophy

15. It's a great big one

16. His name is Red Cloud

17. I don't take care of him

18. Last time I really lead him good

19. He started acting up on me

20. So I quit leading him

21. I only like tame horses

22. She don't have a horse

23. Barry's about that big

24. My brother Timmy he's older he's nine

25. He's about that big to me

26. I don't know

27. I can't ride racing horses

28. I rode once

29. Did Leah get to play with these trucks?

30. My friend that goes in my room

31. He went on an airplane about this big

32. What's that guy do?

33. How many kids come up here?

34. It's as big as my arm

35. I don't have nothing to say no more

36. My brother learnt me some tricks

37. When you're going down the court you swing it over

38. Then is there's not one at the bottom you can shoot

39. Then you have a point

40. Can I have one of these other stickers?

41. Going away in one of those things

42. Walking around a cliff 
43. Go climbing up there

44. He's sking

45. That shark's pulling him

46. They got a fish right there

47. Big Bird driving a big boat

48. This guy's feeding that rabbit

49: They're singing

50. This time I get to ride on my own 
TYPICAL LANGUAGE SAMPLE RESERVATION INDIAN GROUP B

1. A dump truck

2. No but my dad took me in one before

3. Yeah a purple car

4. He's waving

5. He's looking at that horse pulling a wagon of hay

6. Now he's pulling the wagon with the hay in it

7. He resting and he falled down

8. That tipped over

9. He's looking at that cow

10. He talking on the other side of that wood

11. He's scared because he sees the mean bull right in back of him

12. He has to sit on eggs

13. They hatched on him

14. The father and mother got mad at him

15. They're chasing him

16. He's walking through lots of ducks

17. He won't go in the water

18. He falled in

19. He's all wet

20. He's gonna take and go home

21. Mad from soaking wet

22. He's with the pigs in that mud

23. He's with all those animals

24. He's feeding the chicks

25. He's gitting looked at

26. My parents, went on a plane

27. My parents went to Africa

28. Stayed home

29. My aunt Tammy babysitted us

30. They ran into the airplane

31. Then they took off

32. Back and landed and came back

33. And got all packed up and went camping

34. My dad he thought we should make some deer meat

35. My dad and, me went hunting

36. He was shot and he missed it

37. He hit a tree

38. I shot a deer

39. The deer shot right in the stomach

40. Yeah and he shot the tree

41. He doesn't like being out with camping

42. He gets scared 
43. Cries all night

44. You have to go take him and bring him home next day till babysitter come back

45. My sister she can't swim but'I can

46. She can just swim in about that deep of water

47. I can swim in that deep

48. I jumped off the bridge

49. I dove under

50. I caught a fish with my hands 


\section{APPENDIX H}

\section{TYPICAL LANGUAGE SAMPLE URBAN WHITE GROUP C}

1. A brother and he's four years old

2. He hits me and punches me

3. I just say "ouch that hurts"

4. You're gonna get it

5. He gets it all right

6. I have a dog

7. He likes me

8. He licks me al1 over the face when I come home

9. He thinks I'm his mother dog

10. I don't know

11. Yeah cause we had a flood downstairs and now we have to sleep upstairs

12. One day when I came home my mom was crying

13. She was calling most everybody

14. Trying to get somebody to help her

15. She couldn!t even get downstairs

16. She had to call about the whole city

17. Finally we got Laurie's mom across the street to help

18. When I was trying to help my mom these other people came and helped us

19. He always gets in trouble

20. What does he do?

21. He gets in trouble sometimes

22. He tries to fall off a cliff

23. Once I saw. Pink Panther fall off a cliff

24. He bumped his head and on the cartoons they have lumps come out of their head

25. They came way out to there from falling down the hill

26. You spin a dice

27. There's four dice

28. You get a six or a one then you get to go out

29. You have a certain color of marble

30. I'm the champion of that game

31. That's my favorite thing

32. Sometimes I can do them backwards but sometimes I fall

33. I like to jumprope

34. Flying a big balloon

35. Climbing up a mountain

36. The bird's talking to a gopher

37. Sking with a whale

38. You are dumb Big Bird

39. He's holding a fish 
40. He's captain of a ship

41. He's rowing a boat

42. He's feeding corn to the hippopotamus

43. He's feeding a carrot to a rabbit

44. He's playing a trumpet

45. Where's that little bird?

46. He's hiding from me

47. The one on tv I don't know what it's called

48. He's driving a train

49. He's pretending like he's a captain driving on that train but it's really a play train

50. This is where I used to live 
AGE, HEARING VOCABULARY, AND. SCORES BY SUBJECT IN URBAN GROUP A

\begin{tabular}{|c|c|c|c|c|c|c|c|c|c|c|c|c|c|}
\hline 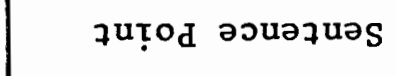 & i & 요 & $\stackrel{m}{\circ}$ & q & \& & సे & $\hat{m}$ & $\vec{t}$ & $\stackrel{\infty}{m}$ & $\stackrel{m}{m}$ & जे & $\stackrel{m}{m}$ & ơ \\
\hline uoțzsəno-4M & 0 & 0 & $a$ & $N$ & 0 & 0 & 0 & 0 & 0 & 0 & $0^{\prime}$ & $\infty$ & 0 \\
\hline 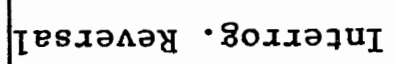 & 0 & 0 & 0 & 0 & 0 & 0 & 0 & 0 & 0 & 0 & 0 & ง & 0 \\
\hline uoţ zoun [uos & ลี & $\stackrel{n}{?}$ & $\stackrel{\infty}{\checkmark}$ & สู & $\vec{v}$ & $\underset{\infty}{m}$ & $\underset{-1}{\infty}$ & 웅 & $\stackrel{a}{\vec{y}}$ & $\vec{\infty}$ & $\hat{\infty}$ & $\ddot{m}$ & న \\
\hline 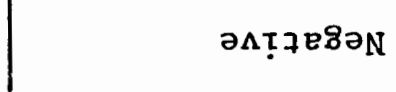 & $r$ & 0 & 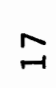 & 0 & t & $\rightarrow$ & $\vec{v}$ & 0 & $\stackrel{\circ}{N}$ & $\stackrel{m}{m}$ & r & $\exists$ & oิ \\
\hline 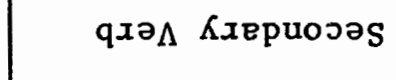 & $\stackrel{n}{-1}$ & $\stackrel{n}{\sim}$ & $\stackrel{\sim}{\sim}$ & $\stackrel{n}{\rightarrow}$ & $\tilde{m}$ & $\stackrel{m}{\rightarrow}$ & $\stackrel{ \pm}{\neg}$ & $\stackrel{N}{*}$ & 욱 & $\exists$ & 욱 & 오 & $\stackrel{\sim}{N}$ \\
\hline 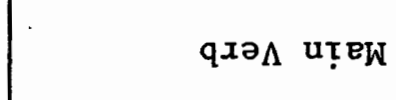 & $\dot{\infty}$ & $\hat{0}$ & $\stackrel{m}{\infty}$ & $\stackrel{m}{n}$ & 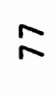 & in & $\stackrel{\circ}{\circ}$ & ○ & $\hat{\circ}$ & $\stackrel{a}{\Rightarrow}$ & 2 & $\stackrel{0}{1}$ & ส \\
\hline unouox $_{d}$ [Euosiod & $\stackrel{\infty}{=}$ & $\infty$ & ळ & ㅇ & $\underset{\sim}{\stackrel{T}{*}}$ & $\frac{n}{2}$ & ஜ & $\underset{ \pm}{ \pm}$ & n & o & ஃ & న & ১ \\
\hline unouoxd $ә$ & $\stackrel{\infty}{+}$ & in & 요 & $\mathfrak{N}$ & $\hat{N}$ & iे & \pm & ํํ & กี & in & N & $\stackrel{\infty}{\rightarrow-1}$ & 운 \\
\hline $\operatorname{ss} \alpha$ & ஜ्లે & $\underset{0}{\stackrel{N}{*}}$ & $\begin{array}{l}\stackrel{8}{\circ} \\
\stackrel{1}{ }\end{array}$ & 욱. & $\begin{array}{l}\stackrel{\circ}{\circ} \\
\stackrel{0}{ }\end{array}$ & $\begin{array}{l}\infty \\
\stackrel{0}{0} \\
\dot{0}\end{array}$ & $\stackrel{\infty}{\stackrel{\infty}{\infty}}$ & $\begin{array}{l}\dot{0} \\
\dot{\infty}\end{array}$ & సे & $\begin{array}{l}\infty \\
\infty \\
\infty \\
\infty\end{array}$ & $\begin{array}{l}\text { ț } \\
\dot{\infty}\end{array}$ & 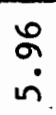 & $\begin{array}{l}\stackrel{0}{\infty} \\
\stackrel{0}{0}\end{array}$ \\
\hline ل'TW & $\stackrel{+}{n}$ & ڤִ & $\stackrel{+}{\circ}$ & $\stackrel{\infty}{\dot{0}}$ & $\dot{\theta}$ & $\begin{array}{l}0 \\
\dot{0}\end{array}$ & $\stackrel{0}{r}$ & ?ִ & $\stackrel{\infty}{r}$ & $\stackrel{N}{0}$ & $\dddot{N}$ & 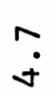 & $\stackrel{0}{0}$ \\
\hline $\mathrm{I} \Lambda \mathrm{dd}$ & $\begin{array}{l}0 \\
1 \\
\vdots \\
0\end{array}$ & ? & $\mathfrak{l}$ & $\begin{array}{l}\infty \\
1 \\
b\end{array}$ & $\stackrel{m}{r}$ & $\begin{array}{c}p \\
1 \\
\sim\end{array}$ & $\stackrel{i}{i}$ & $\stackrel{m}{r}$ & $\begin{array}{l}\overrightarrow{1} \\
\infty\end{array}$ & $\begin{array}{l}\infty \\
1 \\
b\end{array}$ & bا & b & $\begin{array}{l}7 \\
-1 \\
\infty\end{array}$ \\
\hline 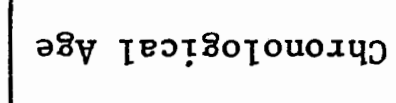 & $\ddot{r}$ & $\stackrel{9}{0}$ & $\stackrel{\Upsilon}{r}$ & $\stackrel{0}{0}$ & $\stackrel{m}{r}$ & $\stackrel{\circ}{r}$ & $\grave{0}$ & $\begin{array}{l}\infty \\
\dot{0}\end{array}$ & $\stackrel{m}{r}$ & $\stackrel{\circ}{r}$ & $\stackrel{\circ}{\circ}$ & $\begin{array}{l}\infty \\
\dot{0}\end{array}$ & $\stackrel{\infty}{0}$ \\
\hline - oN 700 [qnS & $\rightarrow$ & $N$ & $m$ & $\checkmark$ & in & 0 & $\Lambda$ & $\infty$ & $a$ & $\stackrel{ }{-1}$ & $\exists$ & $\mathcal{T}$ & $\stackrel{m}{\rightarrow}$ \\
\hline
\end{tabular}


AGE, HEARING VOCABULARY, AND SCORES BY SUBJECT

IN RESERVATION INDIAN GROUP B

\begin{tabular}{|c|c|c|c|c|c|c|c|c|c|c|c|c|c|}
\hline 7uṬod əouəłuəs & $\vec{m}$ & $\grave{\sim}$ & $\tilde{m}$ & $\stackrel{\leftrightarrow}{N}$ & $\stackrel{m}{m}$ & $\vec{m}$ & ले & $\stackrel{\circ}{\sim}$ & $\stackrel{\sim}{v}$ & 을 & $\stackrel{m}{m}$ & $\stackrel{\operatorname{n}}{\sim}$ & $\stackrel{\infty}{m}$ \\
\hline uoț 7 sand-4M & 0 & 0 & 0 & 0 & N & $N$ & $N$ & 0 & 0 & 0 & 0 & 0 & 0 \\
\hline 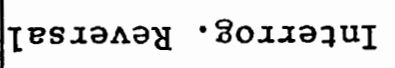 & 0 & 0 & $\underset{\sim}{N}$ & 0 & $a$ & 0 & 0 & 0 & 0 & 0 & -1 & 0 & 0 \\
\hline uoţoun[̣oo & $\stackrel{m}{v}$ & $\stackrel{+}{\sqsupset}$ & $\stackrel{y}{\mathcal{Y}}$ & $\stackrel{\infty}{\sim}$ & $\stackrel{n}{\mathfrak{y}}$ & $\stackrel{m}{\infty}$ & $\stackrel{y}{f}$ & กั & $\stackrel{n}{\circ}$ & कृ & $\stackrel{0}{2}$ & よั & $\stackrel{\circ}{\sim}$ \\
\hline . $\quad ว \wedge โ 7 \mathrm{E8 \partial}$ & 윽 & $\stackrel{0}{\sim}$ & $\infty$ & 0 & -1 & $\underset{\sim}{\sim}$ & $\stackrel{\sim}{\sim}$ & 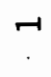 & $N$ & $\checkmark$ & $a$ & $n$ & 0 \\
\hline 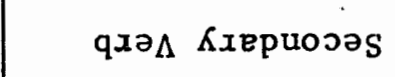 & in & + & $\stackrel{-1}{N}$ & $\stackrel{m}{m}$ & $\stackrel{9}{-1}$ & 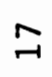 & $\underset{f}{q}$ & 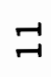 & $\stackrel{\infty}{\sim}$ & $\stackrel{m}{v}$ & 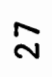 & $\stackrel{a}{r}$ & $N$ \\
\hline$q x \partial \Lambda$ uṬK & $\stackrel{9}{9}$ & $\infty$ & ๗ & $\stackrel{m}{m}$ & $\stackrel{g}{g}$ & $\stackrel{\infty}{\infty}$ & 옹 & $\stackrel{\infty}{+}$ & m & 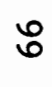 & N & $\infty$ & in \\
\hline unouoxd Ieuosxəd & mె & 옥 & $\infty$ & $\stackrel{\infty}{\text { in }}$ & $\infty$ & 옴 & ิ & ○ & ฉั & $\stackrel{\infty}{\sim}$ & $\infty$ & @ & นึ \\
\hline unouoxd ә7?uтfәpuI & I & $\stackrel{n}{\sim}$ & $\vec{m}$ & 오 & $\stackrel{\mathcal{Y}}{\mathcal{N}}$ & $\exists$ & m & in & 임 & $\infty$ & $\mathfrak{y}$ & in & $\infty$ \\
\hline ssa & $\begin{array}{l}\infty \\
\dot{\infty} \\
\dot{p}\end{array}$ & $\stackrel{\sim}{m}$ & $\begin{array}{l}0 \\
\dot{1} \\
\dot{0}\end{array}$ & $\begin{array}{l}\stackrel{\rho}{+} \\
\dot{m}\end{array}$ & $\stackrel{\circ}{\stackrel{0}{n}}$ & in & $\begin{array}{l}8 \\
\infty \\
\infty\end{array}$ & $\begin{array}{l}N \\
\infty \\
\text { in }\end{array}$ & $\stackrel{\infty}{\infty}$ & $\underset{N}{N}$ & $\stackrel{0}{\stackrel{0}{-}}$ & $\stackrel{\circ}{\text { m }}$ & $\begin{array}{r}\underset{N}{n} \\
\dot{n}\end{array}$ \\
\hline У'TW & $\vec{j}$ & $\stackrel{v}{0}$ & ن & $\stackrel{0}{0}$ & a & ט & ف & $\stackrel{+}{0}$ & $\stackrel{+}{0}$ & $\stackrel{0}{R}$ & ن & $\underset{0}{\infty}$ & $\stackrel{+}{\dot{H}}$ \\
\hline $\mathrm{L} \Lambda \mathrm{dd}$ & $\stackrel{m}{b}$ & $\begin{array}{l}\overrightarrow{7} \\
\overrightarrow{1} \\
\infty\end{array}$ & $\stackrel{1}{1}$ & $\stackrel{1}{r}$ & $\stackrel{\infty}{1}$ & $\overrightarrow{1}$ & $\begin{array}{l}n \\
\infty \\
\infty\end{array}$ & b & $\begin{array}{l}0 \\
\text { 검 } \\
6\end{array}$ & 'ౌ & $\begin{array}{l}0 \\
1 \\
1\end{array}$ & $\begin{array}{l}9 \\
1 \\
\infty\end{array}$ & b \\
\hline 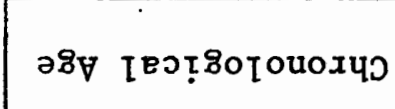 & $\stackrel{\infty}{\dot{b}}$ & $\ddot{-}$ & ? & $\stackrel{0}{\circ}$ & ๑ & $\stackrel{-}{r}$ & $\stackrel{\sim}{r}$ & $\stackrel{m}{r}$ & ம. & ${ }^{\infty}$ & $\underset{\overrightarrow{0}}{\overrightarrow{7}}$ & $\underset{\sigma}{\vec{\sigma}}$ & $\stackrel{\sim}{\sim}$ \\
\hline$\cdot 0_{N} 70 \partial$ [qnS & - & $N$ & $m$ & t & in & 6 & N & $\infty$ & $a$ & $\stackrel{0}{\circ}$ & $\underset{-1}{7}$ & $\stackrel{N}{*}$ & $m$ \\
\hline
\end{tabular}


APPENDIX $\mathrm{K}$

AGE, HEARING VOCABULARY, AND SCORES BY SUBJECT IN URBAN WHITE GROUP C

\begin{tabular}{|c|c|c|c|c|c|c|c|c|c|c|c|c|c|}
\hline 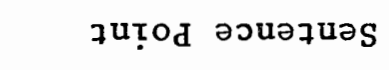 & $\mathcal{y}$ & $\stackrel{\text { in }}{4}$ & $\stackrel{\text { in }}{f}$ & $\stackrel{1}{q}$ & $\stackrel{m}{y}$ & $\stackrel{n}{5}$ & in & $\stackrel{m}{y}$ & $\stackrel{\infty}{\Im}$ & $\stackrel{9}{y}$ & 夺 & t & $\stackrel{\mathcal{Y}}{\mathcal{H}}$ \\
\hline uoțzsano-4M & 0 & t & 0 & g & $\sim$ & هi & 0 & 0 & 0 & 0 & $\sim$ & 0 & 0 \\
\hline IEsxәләу · ৪олдә7UI & 0 & $\underset{-1}{N}$ & 0 & -1 & 0 & 0 & 0 & 0 & 0 & 0 & 0 & 0 & 0 \\
\hline uoț & $\hat{\infty}$ & $\bigsqcup^{+}$ & $\stackrel{0}{\underset{\sim}{\sim}}$ & n & $\infty$ & 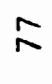 & $\hat{n}$ & $\propto$ & $\stackrel{0}{R}$ & $\stackrel{+}{\infty}$ & $\underset{ت}{\stackrel{J}{二}}$ & $\mathscr{\sim}$ & $\stackrel{n}{n-1}$ \\
\hline$\partial \Lambda ! \neg 8 \not \partial N$ & "m & $\stackrel{n}{n}$ & 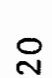 & $\stackrel{9}{9}$ & 욜 & $\stackrel{m}{-1}$ & 政 & $\stackrel{0}{-1}$ & $N$ & t & $\underset{-1}{N}$ & 0 & of \\
\hline 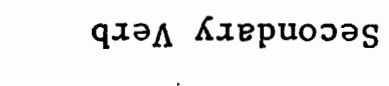 & $\stackrel{N}{\sim}$ & $\vec{m}$ & 0 & $\tilde{v}$ & 6 & 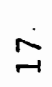 & $\stackrel{\sigma}{-1}$ & $\vec{N}$ & $\underset{\varpi}{\beth}$ & $\hat{N}$ & $\underset{n}{N}$ & in & ङे \\
\hline 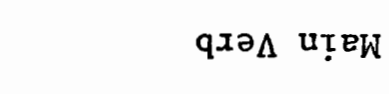 & $\stackrel{m}{\sim}$ & $\stackrel{\sim}{m}$ & $\vec{n}$ & $\mathfrak{n}_{-1}^{n}$ & $\infty$ & $\underset{\sim 1}{\infty}$ & $\stackrel{0}{\sim}$ & ఎ & $\begin{array}{l}\alpha \\
\alpha\end{array}$ & $\stackrel{1}{\circ}$ & $\stackrel{n}{n}$ & $\sigma$ & $\stackrel{a}{+}$ \\
\hline unouoxd [euosxəd & $\stackrel{m}{\sim}$ & $\stackrel{0}{\rightarrow-1}$ & $\stackrel{\infty}{\rightarrow}$ & 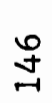 & $\stackrel{m}{\rightarrow-1}$ & a & $\underset{\substack{0 \\
-1}}{0}$ & $\hat{\infty}$ & $\stackrel{r-1}{0}$ & 응 & 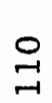 & $\underset{\sim}{\sim}$ & $\stackrel{\circ}{\circ}$ \\
\hline unouoxd 37 țutgəpuI & $\pi$ & in & ชี & oิ & $\stackrel{9}{N}$ & $\hat{\sigma}$ & ร & \& & $\stackrel{m}{y}$ & $\overrightarrow{0}$ & कै & $\stackrel{n}{n}$ & పे \\
\hline sSa & $\underset{-1}{\stackrel{N}{-1}}$ & $\stackrel{\text { m}}{\text { m }}$ & $\begin{array}{l}+ \\
\infty \\
0\end{array}$ & $\begin{array}{l}\stackrel{+}{0} \\
\stackrel{\sim}{\sim}\end{array}$ & $\begin{array}{l}\stackrel{N}{\sim} \\
\infty\end{array}$ & $\underset{\infty}{\stackrel{N}{\sim}}$ & $\stackrel{\sim}{\sim}$ & $\begin{array}{l}0 \\
\text { n }\end{array}$ & ํํํ & $\underset{\infty}{\stackrel{N}{V}}$ & $\begin{array}{l}\text { a } \\
\dot{\sigma}\end{array}$ & ن & 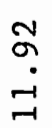 \\
\hline ষ'TW & $\tilde{0}$ & $\stackrel{\sim}{N}$ & $\ddot{0}$ & $\stackrel{\ddots}{r}$ & $\dot{v}$ & 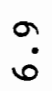 & $\because$ & $\stackrel{0}{0}$ & $\ddot{0}$ & : & $\stackrel{n}{n}$ & $\dot{0}$ & $\stackrel{\sim}{\infty}$ \\
\hline $\mathrm{I} \Lambda \mathrm{dd}$ & $\begin{array}{l}0 \\
1 \\
0 \\
\text {. }\end{array}$ & $\begin{array}{l}1 \\
1 \\
0\end{array}$ & $\begin{array}{l}\infty \\
1 \\
a\end{array}$ & $\underset{I}{+}$ & $\stackrel{m}{1}$ & İ & $\frac{1}{1}$ & $\stackrel{m}{r}$ & $\stackrel{m}{r}$ & $\begin{array}{l}-1 \\
1 \\
0\end{array}$ & $\frac{\infty}{1}$ & $p_{1}^{m}$ & $\stackrel{0}{\stackrel{1}{1}}$ \\
\hline 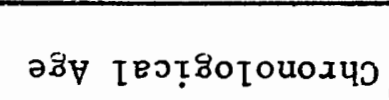 & $\stackrel{+}{r}$ & $\ddot{0}$ & ت & $\dot{0}$ & $\dot{v}$ & ت्1 & $\stackrel{0}{0}$ & $\ddot{r}$ & 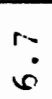 & $\dot{r}$ & $\stackrel{0}{r}$ & $\stackrel{0}{\sim}$ & $\stackrel{m}{n}$ \\
\hline$\cdot \mathrm{ON}_{\mathrm{N}} 70 \partial[\mathrm{qnS}$ & -1 & $N$ & $m$ & $\checkmark$ & $n$ & 0 & $r$ & $\infty$ & $a$ & $\stackrel{0}{9}$ & $\stackrel{-}{r}$ & $\underset{\sim}{\sim}$ & $m$ \\
\hline
\end{tabular}

